\title{
Type C Investigation of Electrical Fabrication Projects in ICF Kaiser Shops
}

Prepared for the U.S. Department of Energy Office of Environmental Restoration and Waste Management

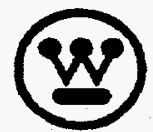

Westinghouse

Hanford Company Fichland, Washington

Management and Operations Contractor for the U.S. Department of Energy under Contract DE-AC06-87RL10930 
LEEAL DISCLAMER

This report was prepared as an account of work sponsored by an agency of the United States Government. Neither the United States Government nor any agency thereof, nor any of their employees, nor any of their contractors, subcontractors or their employees, makes any warranty, express or implied, or assumes any legal liability or responsibility for the accuracy, completeness, or any third party's use or the results of such use of any information, apparatus, product, or process disclosed, or represents that its use would not infringe privately owned rights. Reference herein to any specific commercial product, process, or service by trade name, trademark, manufacturer, or otherwise, does not necessarily constitute or imply its endorsement, recommendation, or favoring by the United States Government or any agency thereof or its contractors or subcontractors. The views and opinions of authors expressed herein do not necesserily state or reflect those of the United States Government or any agency thereof.

This report has been reproduced from the best available copy. Available in paper copy and microfiche.

Available to the U.S. Department of Energy and its contractors from

Office of Scientific and Technical Information

P.O. Box 62

Oak Ridge, TN 37831

(615) $576-8401$

Available to the public from the U.S. Department of Commerce National Technical Information Service

5285 Port Royal Road

Springfield, VA 22161

(703) 487-4650

Printed in the United States of America

DISCLM-1.CHP (1-91) 


\section{DISCLAIMER}

Portions of this document may be illegible in electronic image products. Images are produced from the best available original document. 


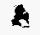

\section{RELEASE AUTHORIZATION}

Document Number: $\quad$ WHC-MR-0505

Document Title: $\quad$ Type C Investigation of Electrical Fabrication Projects in ICF Kaiser Shops

Release Date: $\quad 7 / 5 / 95$

This document was reviewed following the procedures described in WHC-CM-3-4 and is:

APPROVED FOR PUBLIC RELEASE

WHC Information Release Administration Specialist:

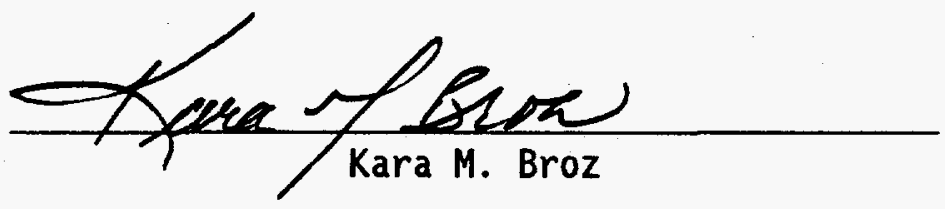


WHC-MR-0505

TYPE C INVESTIGATION

\section{ELECTRICAL FABRICATION PROJECTS}

IN ICF KH SHOPS

Investigation Board:

R. A. Huckfeldt, Chairman, WHC TWRS IS\&FP

K. W. Leliefeld, Mgr. TWRS Maintenance Programs

J. G. Holyoak, ICF KH Shop Manager

P. H. Thomsen, TWRS Maintenance Programs

J. D. van Heel, ICF KEH Electrical Engineer

D. O. Wallace, ICF KH NEC Qual ified Inspector

J. Weber, TWRS Quality Assurance Manager

Date Published

June, 1995 


\section{APPROVALS}

\section{P.Q. Nuchpalats}

R. A. Huckfeldt, Chairman, $6 / 27 / 95$ Type C Investigation Board, Accident Investigator Westinghouse Hanford Company

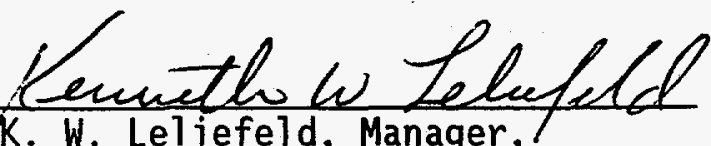

K. W. Leliefeld, Manager,

TWRS Maintenance Programs/P1ant Projects Westinghouse Hanford Company

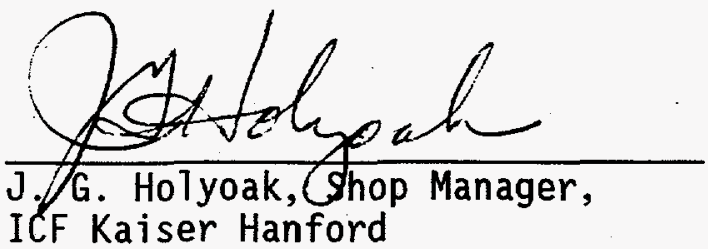

O. M. Momsen

P. H. Thomsen, Manager,

TWRS Plant Modifications

Westinghouse Hanford Company

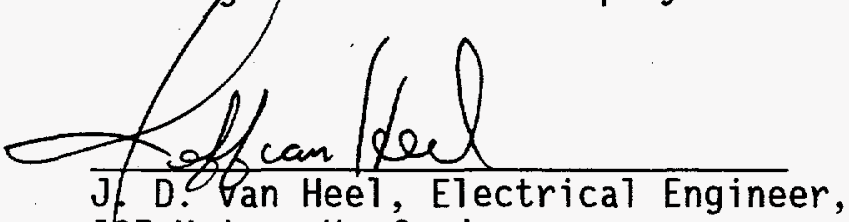

ICF Kaiser Hanford

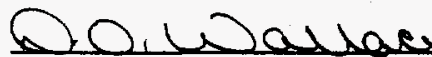

D. 0. Wallace, Compliance Inspector, Quality Inspection Services

ICF Kaiser Hanford

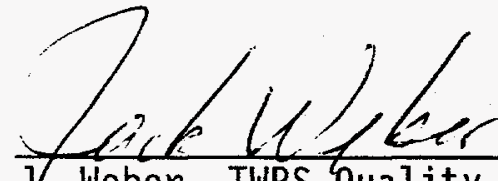

3). Weber, TWRS Quality Assurance Manager, Westinghouse Hanford Company
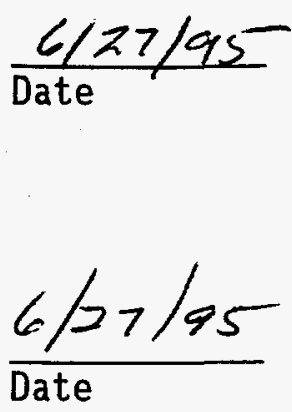

$\frac{6 / 27 / 95}{\text { Date }}$
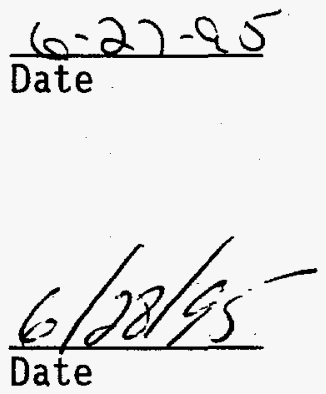
CONTENTS

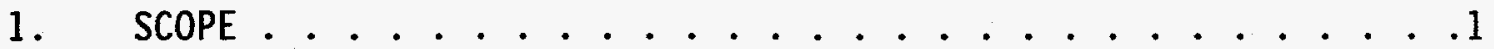

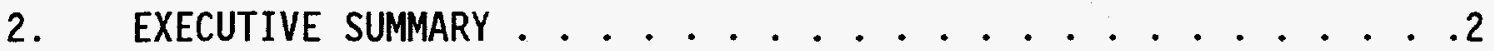

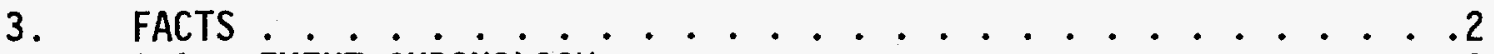

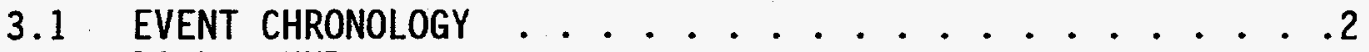

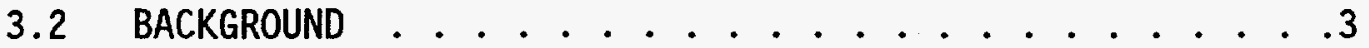

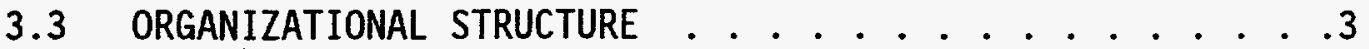

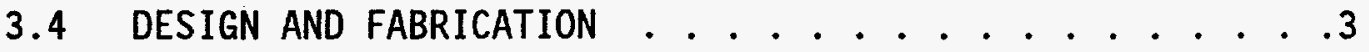

4. ANALYSIS . . . . . . . . . . . . . . 4

4.1 ANALYSIS OF FABRICATED EQUIPMENT . . . . . . . . . . . 5

4.2 MANAGEMENT ASSESSMENT . . . . . . . . . . . . . . . . . 5

4.3 EVENTS AND CAUSAL FACTORS ANALYSIS $\ldots . . .7 .7$

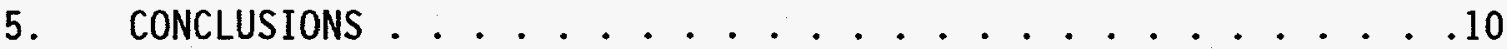

5.1 SAFETY CLASSIFICATION . . . . . . . . . . . . .

5.2 COGNIZANT ENGINEERS . . . . . . . . . . . . . 10

5.3 DESIGN. . . . . . . . . . . . . . . . 10

5.4 FABRICATION SHOPS ..................... . . . .

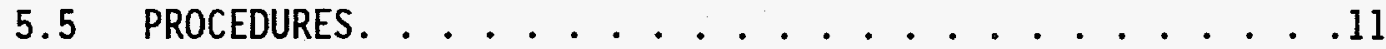

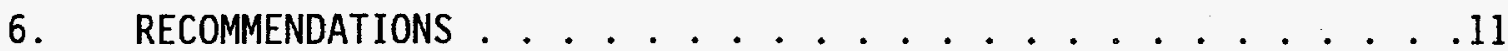

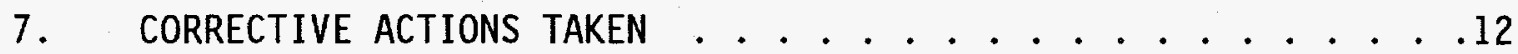

8. FIGURES . . . . . . . . . . . . . . . . . . . . . .

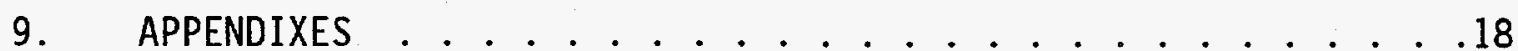

APPENDIX $1 \ldots \ldots$

APPENDIX 2. . . . . . . . . . . . . . . . . . . . . . .

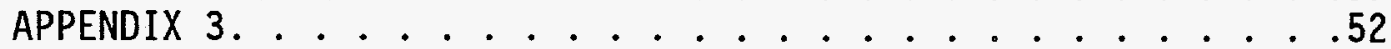


WHC-MR-0505

Page 1

\section{TYPE C INVESTIGATION, ELECTRICAL FABRICATION PROJECTS IN ICF KH SHOPS}

\section{SCOPE}

A Type C Investigation Board was convened to investigate an electrical miswiring problem found during the operation of the electrical distribution trailer for the TWRS Rotary Mode Core Sampling Truck \#2. The trailer was designed by WHC and fabricated ICF KH on site for use in the Characterization Program. This problem resulted in a serious safety hazard since the support truck frame/chassis became electrically energized.

This final report provides results of the "Type $C$ Investigation, Electrical Fabrication Projects in ICF KH Shops, June, 1995." It contains the investigation scope, executive summary, relevant facts, analysis, conclusions and corrective actions. DOE Order 5484.1, "Environmental Protection, Safety and Health Protection Information Reporting Requirements, "was followed in preparation of this report.

Because the incident was electrical in nature and involved both Westinghouse Hanford Company and ICF Kaiser Hanford organizations, the board included members from both contractors and members with considerable electrical expertise. The investigation included:

- A review of all TWRS electrical projects that were in process at the ICF $\mathrm{KH} 272 \mathrm{E}$ shop was conducted for conformance with drawings, adequacy of acceptance testing, and code compliance of fabrication.

- A design review of all TWRS electrical projects that were in process at the ICF KH $272 E$ shop was conducted to confirm that the functional requirements were satisfied by the completed hardware.

- A management assessment was conducted of TWRS organizations that are involved with the in-house design and fabrication efforts.

- Performance of extensive interviews.

- Analysis of the events.

- Identification of contributing and root causes for identified deficiencies.

- Identification of actions needed to prevent recurrence. 
WHC-MR-0505

Page 2

\section{EXECUTIVE SUMMARY}

On April 10, 1995, swing shift, the Core Sampling Field Team was in the process of setting up and staging the Rotary Mode Core Sampling Truck \#2 and ancillary equipment in the West Tank Farms, for the purpose of obtaining a push-mode core sample from waste tank S-107. During troubleshooting of the electrical power systems associated with the core sampling truck, it was discovered that wiring from the portable 37.5 KVA transformer to the power supply leads coming from the transformer were improperly connected.

It was determined that fabrication of the transformer distribution wiring resulted in a ground wire being improperly connected to a 120 volt "hot lead." When the power supply leads coming from the transformer were connected to the water supply truck, the truck frame, normally connected to ground, was energized with 120 volts. No personnel injuries resulted from this event.

Since this was classified as a near miss and no accident occurred, there is not a direct cause. The root and contributing causes have been identified as a combination of less than adequate conditions in three broad categories; cognizant engineers, design control, and fabrication shops.

\section{FACTS}

The purpose of this section is to provide facts relevant to the event. It describes facts surrounding organizational structures, design, event evolution, and post events.

\subsection{EVENT CHRONOLOGY}

On April 10, 1995, swing shift, the Core Sampling Field Team was in the process of setting up and staging the Rotary Mode Core Sampling Truck \#2 and ancillary equipment in the West Tank Farms, for the purpose of obtaining a push-mode core sample from waste tank S-107. During troubleshooting of the electrical power systems associated with the core sampling truck, it was discovered that wiring from the portable $37.5 \mathrm{KVA}$ transformer to the power supply leads coming from the transformer were improperly connected.

It was determined that fabrication of the transformer distribution wiring resulted in a ground wire being improperly connected to a 120 volt "hot lead." When the power supply leads coming from the transformer were connected to the water supply truck, the truck frame, normally connected to ground, was energized with 120 volts (Figure 1). Westinghouse Hanford Company established a Type $C$ Investigation Board to investigate the incident. A decision was made by the ICF Kaiser Fabrication Shops management to stop electrical work until the investigation was conducted.

The investigation activities were broken into three parts: 
WHC-MR-0505

Page 3

1. A team investigated NEC compliance, $Q A / Q C$ requirements, testing and constructability for 19 projects which were in process at the shop. The team addressed these details for each piece of equipment to ensure that the work could be fabricated per the design media and that the equipment would be safe to operate upon reaching the field. This was done to allow restart of the fabrication process.

2. An assessment of the management and administrative control systems, from requirements definition, design, fabrication requirements, final checkout and delivery was performed. This included an assessment of overall systems problems, personnel qualifications, and organizational interfaces. The assessment was conducted of those organizations that are involved with in-house design and fabrication efforts. The Management Assessment only considered specific equipment identified as having potential electrical problems. The specific items were newly created designs; design and fabrication in support of maintenance activities were not considered within the scope of the assessment.

3. An assessment of the engineering process used to develop the designs and deliver the equipment to ensure the fabricated equipment met the needs of TWRS and was appropriate for installation in Tank Farms was conducted. Items emphasized include: (1) technical design basis for the designs; (2) design criteria; (3) design reviews and design verification; (4) safety basis compliance; and (5) testing. (Appendix 1)

\subsection{BACKGROUND}

Westinghouse Hanford Company (WHC) is contracted to the Department of Energy and is responsible for maintenance and operations of the Hanford site. ICF Kaiser Hanford (ICF-KH) is subcontracted to WHC to provide design engineering and site support services (WHC provided the design for the electrical distribution trailer). As such, significant part of the work done requires personnel involvement from both contractors.

\subsection{ORGANIZATIONAL STRUCTURE}

A basic flow chart was developed to describe the typical process for providing in-house manufactured equipment. (Figure 1) The electrical distribution trailer for the Rotary Mode Core Sampling Truck \#2 involved personnel from both WHC and ICF-KH. The organizations involved were the WHC TWRS Plant Organization, which initiated the work; the WHC TWRS Engineering Organization, which provided the design effort; and the ICF-KH Fabrication Shops, which manufactured the item.

\subsection{DESIGN AND FABRICATION}

The design of the Electrical Distribution Trailer was found to be less than adequate. The design had specified 3 conductor cord reels while 
WHC-MR-0505

Page 4

attempting to utilize 4 conductor cords. The reels specified did not allow for the equipment ground to be continuous through the circuit. The design drawings had shown male plugs on the ends of the cables where the female sockets should have been (Figure 2). This configuration allowed for exposed energized parts, once the transformer was energized. The design called for use of four conductor cord bodies being attached to three conductor cords. There was no connection/wiring diagram included in the design media.

The Fabrication of the Electrical Distribution Trailers was also found to be less than adequate. As shown in Figure 3, the hot lead being attached to the ground wire on the cord reel caused the sample truck frame to become energized. The electrician stated that he informed the engineer of this configuration and the engineer gave him direction to proceed. The engineer denies that he was informed of this configuration, and that he had not given direction to proceed. Regardless, the electrician knew that the configuration was wrong, but proceeded with the installation anyway. Other fabrication errors were found such as inadequate insulation on splices, no ground wire on the 100 amp disconnect, use of type $W$ cable instead of the specified type SOW, 2 " conduit in place of $11 / 2$ " as specified on the drawing.

Nineteen other projects were evaluated for adequacy in the following categories as applicable:

- NEC Design Review

- NEC field inspection

- $\quad Q A / Q C$ requirements defined

- $\quad$ Testing defined

- Constructability review

The design drawings were reviewed for NEC compliance by the NEC Interpretive Authority. Attached in Appendix 2 are the reports compiled for the 19 projects evaluated.

Fabrication work done to date on the 19 projects was also reviewed for NEC compliance via the NEC field inspection. The designated NEC inspector evaluated the equipment at the fabrication shops. Attached in Appendix 3 are the field reports for the 19 projects evaluated.

\section{ANALYSIS}

The analysis section of this report was developed in accordance with the requirements of DOE Order 5484.1, "Environmental Protection, Safety, and Health Protection Information Reporting Requirements." It consists of 
investigators reasoning pertaining to factual information, which supports the conclusions. Additionally, the analysis was developed by the Board to illustrate the interpretation of facts, conditions, circumstances, and inferences which support the findings, probable causes and judgement of needs.

\subsection{Analysis of Fabricated Equipment}

It was found that not all of the projects had $Q A / Q C$ requirements defined pertaining to the electrical installation. Most of the equipment was designated Safety $\mathrm{Class} 4$, therefore, per requirements, $Q A / Q C$ verification was not required. However, for the purpose of re-starting, projects that did not have $Q A / Q C$ requirements in $p l$ ace have had requirements generated by the design engineer. These requirements were reviewed by the $Q A / Q C$ organization and $a Q A / Q C$ inspection $p 1$ an has been generated.

It was found that not all projects had requirements for testing prior to release from the fabrication shops. However, the projects did have testing requirements laid out for the field. Either a specific test for that particular piece of equipment, or part of a system ATP/OTP. For the purpose of re-starting fabrication, every piece of equipment, as applicable, will have a functional test placed in the package for completion prior to release from the shops. In some cases the QA/QC requirements are part of the functional test.

A constructability review was conducted on the 19 projects also. This review consisted of reviewing the work packages (i.e. drawings and ECN's) to determine if all the ECN's were placed in the package and if the design media gave sufficient information to facilitate fabrication by the electricians. It did not review the design criteria or its operational requirements. One package was found to be missing an ECN. other packages, under developmental control, had preliminary ECN's that are to be used for fabrication. The WHC procedure for developmental control drawings allows for this situation to occur (WHC-CM-6-1, EP2.4). Other packages contained numerous ECN's, and while fabrication was possible, it was deemed by this investigation to be confusing for the craft to fabricate, when the need to review so many ECN's was necessary. These packages were allowed to re-start, due to the fact that fabrication services now has an engineering division that can act as Tiaison between the craft and the design authority. The support truck drawings had numerous ECN's, however due to this investigation, the cognizant engineer requested that new drawings be issued incorporating all of the ECN's, which was completed before re-start commenced.

\subsection{Management Assessment}

An entrance meeting was held on Monday, April 24, 1995. The organizations being assessed were the TWRS Plant Organization, the TWRS 
WHC-MR-0505

Page 6

Engineering Organization, and the ICF KH Fabrication Shops. Members of al1 organizations being assessed were present. The scope and intent of the assessment were discussed, as was the schedule. Afternoon meetings were established, so that the organizations being assessed could be made aware of the progress of the assessment and of any potential problem areas discovered by the Assessment Team.

A presentation was made to the Assessment Team by each of the organizations being assessed. The presentation covered organization, process flow and responsibilities.

The analysis is presented in three categories; Cognizant Engineers, Design Control, and Fabrication Shops.

A. Cognizant Engineers

The Cognizant Engineers provide a key role in the activities evaluated during this assessment. They represent the operations organization and are the primary interface with engineering and fabrication services. Procedurally they are given a large amount of responsibility with minimal management oversight. Because of minimal management oversight, these individuals need to possess significant knowledge about the operating systems and the management processes needed to obtain cost-effective support services, including engineering/design, quality assurance, procurement and fabrication. The majority of the Cognizant Engineers that were contacted during this assessment had very few years of related experience to back up their roles and responsibilities.

The Cognizant Engineer is viewed by others as the key individual in:

- developing performance requirements

- make or buy decisions

- development of design and fabrication requirements

- acceptance of completed work.

\section{B. Design Control}

In accordance with the Engineering Practice (EP), WHC-CM-6-1, the preparation of design engineering documentation is driven by an approved work plan. An approved work plan is in turn a product of a defined 10 step process:

- assignment of a cognizant engineer

- definition of work scope and design deliverables

- a determination of the applicable safety

classification and approval designator

- the establishment of design inputs 
WHC-MR-0505

Page 7

- a determination of the required design interfaces

- identification of the required design analysis

- identification of preprocurement and ADP planning requirements

- establish organizational requirements

- determine cost and scheduTe

- the establishment of quality assurance and safety requirements.

Using the work $p l$ an as the design basis, the design/engineering process is undertaken. Again, the flow associated with this process is well defined in the Engineering Practices Guide.

- $\quad$ prepare engineering documents

- verify design (for this equipment use informal design review)

- $\quad$ approve and release engineering documents

Two steps critical to this flow are the work plan and design verification processes. Both these steps are addressed in the Standard Engineering Practices Manual, WHC-CM-1-6, and are mandatory practices.

\section{Fabrication Shops}

The fabrication shop is managed and operated by ICF KH to fabricate components, assemblies and systems to support mainly WHC experimental and development projects. Work related to other schedule sensitive activities is also performed in this shop. There is a mixture of various craft, planners, and supervisory staff including shop superintendent and the shop manager. Additional craft is hired from the union shop when needed. The fabrication shop is authorized to perform a job by the operations Cognizant Engineer by issuing a J-10, "Fabrication Request". The $\mathrm{J}-10$ should reference or contain design media, inspection and testing requirements and other special instructions. The shop fabrication engineer resolves problems with the Cognizant Engineer.

\subsection{Events and Causal Factors Analys is}

Event sequences and conditions were reviewed and validated through interviews and work package documentation. Causal factors were developed where less than adequate conditions were found. Contributing causes are as follows: 
WHC-MR-0505

Page 8

Several less than adequate conditions were detected in the selection and use of the Cognizant Engineers.

a. The title of Cognizant Engineer is too widely used within WHC (i.e., it was difficult to identify who was the actual Cognizant Engineer for a specific design/fabrication activity).

b. The selection, qualification and training requirements have not been formally defined for the Cognizant Engineer position.

c. The roles, responsibilities and authorities of the Cognizant Engineers have not been formally defined.

d. The Cognizant Engineers do not appear to possess an adequate working knowledge of the approved management systems that need to be implemented to ensure that the work is performed cost-effectively and correctly. Some of the processes identified where improvement in Cognizant Engineer knowledge is in order include:

- initiation of engineering/design support

- selection and use of safety classes

- participation in design approval

- procurement of fabrication services by either ICF KH or outside Hanford sources

- selection and use of inspection and testing activities

- performance of acceptance testing and equipment turnover.

A review of the design process reflected several less than adequate conditions.

a. A work $p 1$ an, encompassing the attributes reflected in the EP, had not been developed. A task plan was developed by the design organization, but did not include the required information for a work plan.

b. No documentation indicating that the design had been verified was located. We must note that the absence of a previously developed design requirements base would have made the verification process impossible.

c. Conversations with both the Cognizant Engineer and the lead design engineer reflected confusion in the use and application of the WHC safety classification system. 
WHC-MR-0505

Page 9

d. The lead design engineer did reflect frustration in not having Hanford specific design standard to reference or to work to.

e. Once the design has been released, the design agent/design organization having the responsibility for generating the design may not be involved in the approval of changes made to that design during fabrication.

f. Clear definitions of the terms "design authority" and "design agent" does not exist.

Several less than adequate conditions were detected in work going to, performed, and released to the field from the fabrication shops.

a. It was determined that the fabrication shops were at times provided incomplete or confusing documentation for use when fabricating requested items.

b. Customer expectations to the fabrication shops are not being clearly defined. For example; Cognizant Engineers are of the opinion that acceptance tests prior to release to the field are a normal part of doing business. However, discussions with fabrication personnel revealed that any inspections/tests not specified via the design document and or J-10 are not performed. The fabrication shop did indicate that an operational test was performed on the electrical trailer. It was assumed that a full functional test would be performed in the field.

c. Fabrication shop practices for incorporation of changes to a working drawing provide for notation of the change on the drawing with reference to the ECN that authorized the change. It was observed that this practice is not always adhered to and would allow unapproved changes to design.

d. Shop procedures for the processes such as fabrication, machining, painting, and welding are well defined. However, there is no electrical shop procedure. Quality of electrical work is solely dependent upon the qualifications and experience of the electrician. An electrician with a state certification is considered adequate to perform a qual ity job in accordance with National Electrical Code (NEC), therefore, procedures are not considered necessary. In the case of the electrical distribution trailers, a 
WHC-MR-0505

Page 10

change in the responsible electrician due to health problems, caused a significant impact upon the quality of the electrical work.

e. Supervisor of the electrical trailers was not we11 versed in electrical applications.

\section{CONCLUSIONS}

The conclusions provided below are made in the context of a Management Assessment. They represent the collective wisdom and experience of the members of the team. They are not meant to be prescriptive, but rather broad guidelines to be considered.

\subsection{Safety $\mathrm{Classification}$}

The Safety $\mathrm{Classification} \mathrm{of} \mathrm{a} \mathrm{structure} \mathrm{system} \mathrm{or} \mathrm{component} \mathrm{is} \mathrm{a}$ critical activity. The Safety Classification "turns-on" or "turns-off" the Quality Assurance program and therefore has regulatory, safety and cost/schedule impact. The present Safety Classification system is complex and difficult to implement. Further, beyond the functional design organizations, there is not even a comprehension of the purpose and implication of the Safety Classification system. The Cognizant Engineer is charged with the responsibility of establishing the Safety Classification; they do not have sufficient knowledge or information to do so, on a consistent basis.

\subsection{Cognizant Engineers}

The method by which TWRS does work, is the Cognizant Engineer system. Procedurally, the Cognizant Engineer/Manager is given significant authority and responsibility with minimal management overview. However, there are no standards established for this position, nor is there a means of primary designating someone as a cognizant engineer. There is also a great deal of confusion as to which organization can designate someone as "Cognizant Engineer" (e.g. can you have a Cognizant Design Engineer?)

\subsection{Design}

There continues to be a great deal of confusion as to "design authority" and "design agent". Embroiled within these definitions is the lack of understanding of in which organization the design knowledge and information resides. If the "design authority" has another organization perform the design (i.e. a "design agent") then the "design authority" can not do a design review without the "design agent". This same issue extends to ECN issuance and approval.

The EP 6.1 Manuals must be clarified and the engineers must be required to use them. The issue of guidelines and minimum management 
expectations continues to be a point of confusion. The documentation which establishes the design path and activities is minimal.

\subsection{Fabrication Shops}

The Fabrication Shops must take responsibility for the safety and functionality of the equipment that they manufacture. The interface between the Fabrication Shops and the Plant organization is totally verbal.

There is a lack of defined workmanship standards relative to electrical work. There is a lack of testing procedures relative to electrical work. The shop supervision is weak relative to electrical work.

\subsection{Procedures}

The most important procedures are those which provide information relative to crossing organizations interfaces. During the Management Assessment, three such interfaces were noted; the Cognizant Engineer to the Design Organization, the Cognizant Engineer to the Fabrication Shops to start work; the Fabrication Shops to the Cognizant Engineer to accept the completed work. The lack of understanding by each party at these interfaces was the primary cause of the problems that were encountered.

\section{Recommendations}

1. The title Cognizant Engineer should be restricted to a specific job classification based on an approved job description.

2. Establish requirements for Cognizant Engineer selection, qualification, and training. The assessment team was made aware of internal WHC documents which should provide a good starting point.

3. Establish and implement a document that provides a description of the Cognizant Engineer/Manager's roles, responsibilities and authorities. The documents mentioned in item 2 above can also be used as a starting point for development of this document.

4. Provide newly appointed Cognizant Engineers\Managers with on-thejob training provided by a mentor with a history of success in implementing the established management systems.

5. Management needs to define their usage expectations associated with the guidance reflected in WHC-IP-1026 and the requirements addressed in WHC-CM-6-1. If WHC-IP-1026 is only guidance, then what specifies the minimum expectations to meet the requirements.

6. The design process would benefit if site wide design standards were developed similar to the previously used Hanford Plant Standards. 
WHC-MR-0505

Page 12

7. Changes to the design, occurring during the fabrication process, should include review by the responsible design agent/ design organization in order to ensure design integrity.

8. The development of a fabrication specification by the design agent similar to that developed for off site vendors would benefit on site fabrications efforts.

9. The operations Cognizant Engineer must define his expectations by providing minimum testing and inspection requirements in $\mathrm{J}-10$ or design documents. A fabrication specification should be developed when a complex assembly is required or requested by the fabrication engineer.

10. The Fabrication shop management should develop procedures to include minimum electrical inspection and testing requirements for assuring equipment will function safely.

11. Fabrication shop management should appoint an electrical supervisor.

12. The assessment team was made aware of plans for implementing a J10 Quality checklist. This checklist will be used to review the submitted work request to ensure all necessary documentation is included with each work request. In addition, discussions are underway to develop a new program that would address the use of Quality Control personnel for Safety Class 4 inspections not otherwise identified via the design media. Both actions are considered good starting points for development of the necessary expectations when performing work in the Fabrication shops.

\section{CORRECTIVE ACTIONS TAKEN}

1. To provide confidence that items produced by fabrication shops have been safe and functional, a survey of recent customers outside of TWRS has been performed by the Fabrication Shop management. No problems with worker safety or equipment was reported.

2. The Investigation team reviewed and identified problems and issues with existing work activities and work packages. Through this process, several corrective actions have been taken to allow better oversight of work activities. They are as follows:

- $\quad$ NEC design reviews are required

- Quality Control approved acceptance plan is required

- A functional test is required

- Formal customer acceptance of the work is required

- Customer is notified of the final inspection and testing so they can participate 
- A final NEC review is performed to assure compliance with the electrical codes and standards.

3. Several actions were taken to assure the information obtained from this investigation was communicated sitewide. TWRS immediately sent out Lessons Learned information to all facilities on the Hanford Site and other DOE complexes. The Fabrication Shop management requested information from other customers concerning their products and if there were any safety or functional problems/issues. Fabrication Shop management is working with the other shops on site to assure correction of any common issues.

4. A supervisor with electrical experience has been assigned to oversee work in the fabrication shops.

5. The incident has been discussed with all Fabrication Services electricians, supervisors, and managers involved.

6. The electrician involved in the work on the trailer was a temporary employee and has been terminated (work assignment complete).

7. Responsible level 3 managers (or equivalent) will hold meetings with their people and explain the accountability rules within the new WHC contract and within the Quality Assurance RuTe 10 CFR 830.120 .

8. Responsible engineering managers (e.g. Transition Projects; Characterization and Engineering) will hold meetings with their people to address the Standard Engineering Practices in WHC-CM-6-1 and the guidance in WHC-IP-1026.

9. A series of Systems Engineering briefings will be held for all engineering personnel in various TWRS organizations.

10. Managers will develop qualifications for the Cognizant Engineer. The qualifications will include professional experience, experience within TWRS Tank Farms, education, and a minimum set of training requirements. The qualifications may also include professional engineering status and other certifications.

11. A minimum standard will be established for the Cognizant Engineer. 
WHC-MR-0505

Page 14

FIGURES 


\section{Design Control Flow Chart}

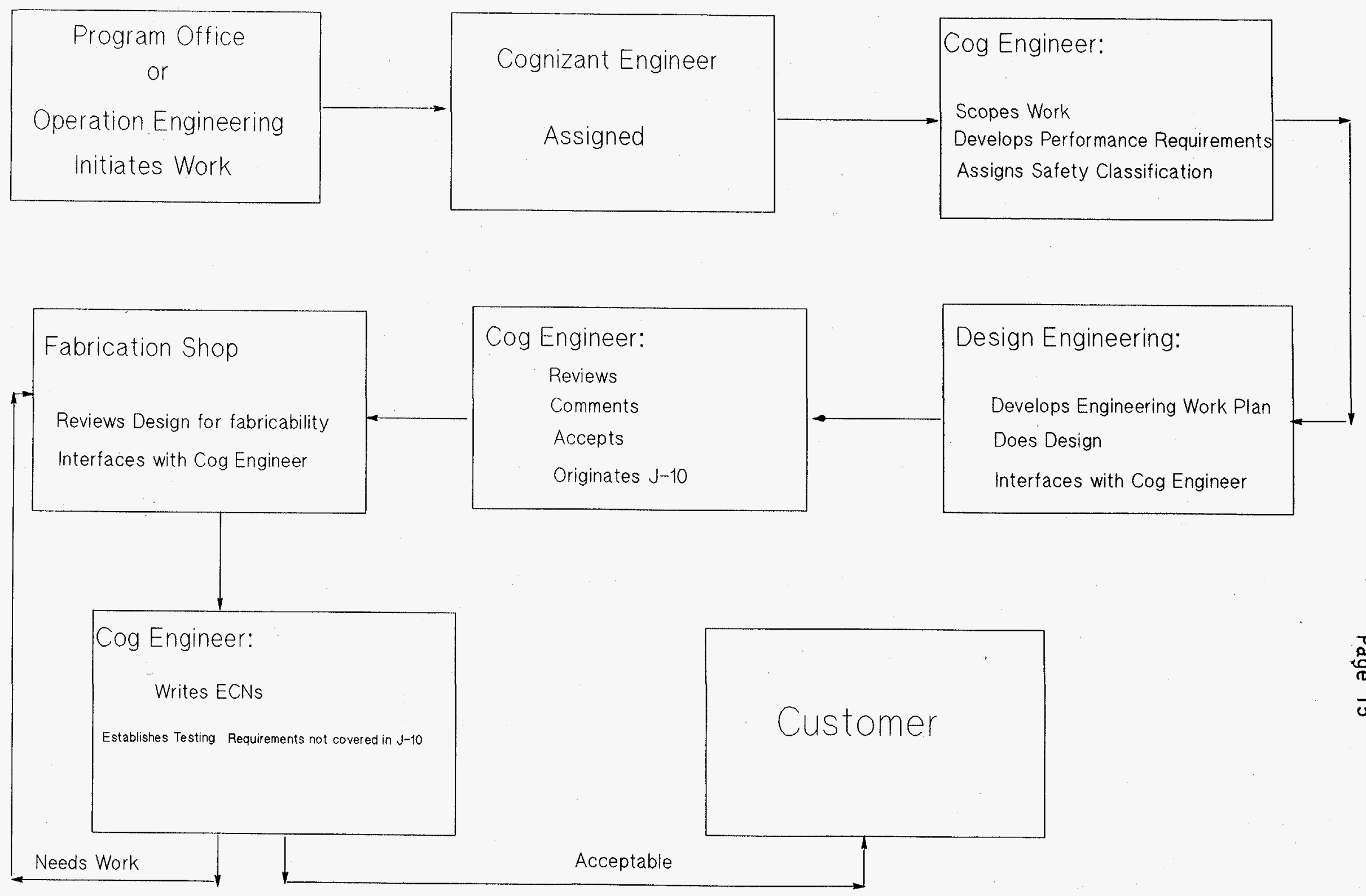


Page 16

$\frac{1}{1}=0$

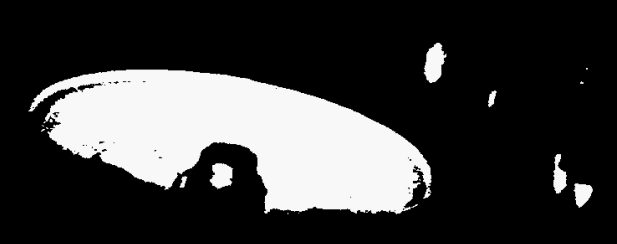

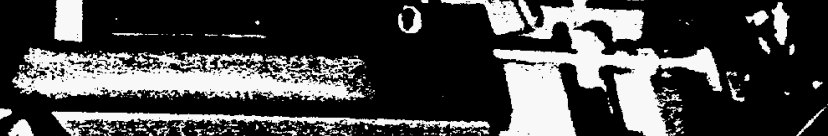

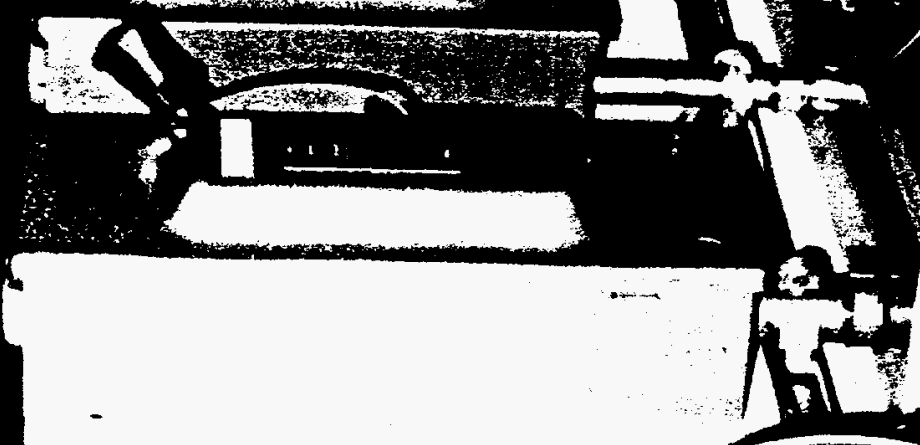




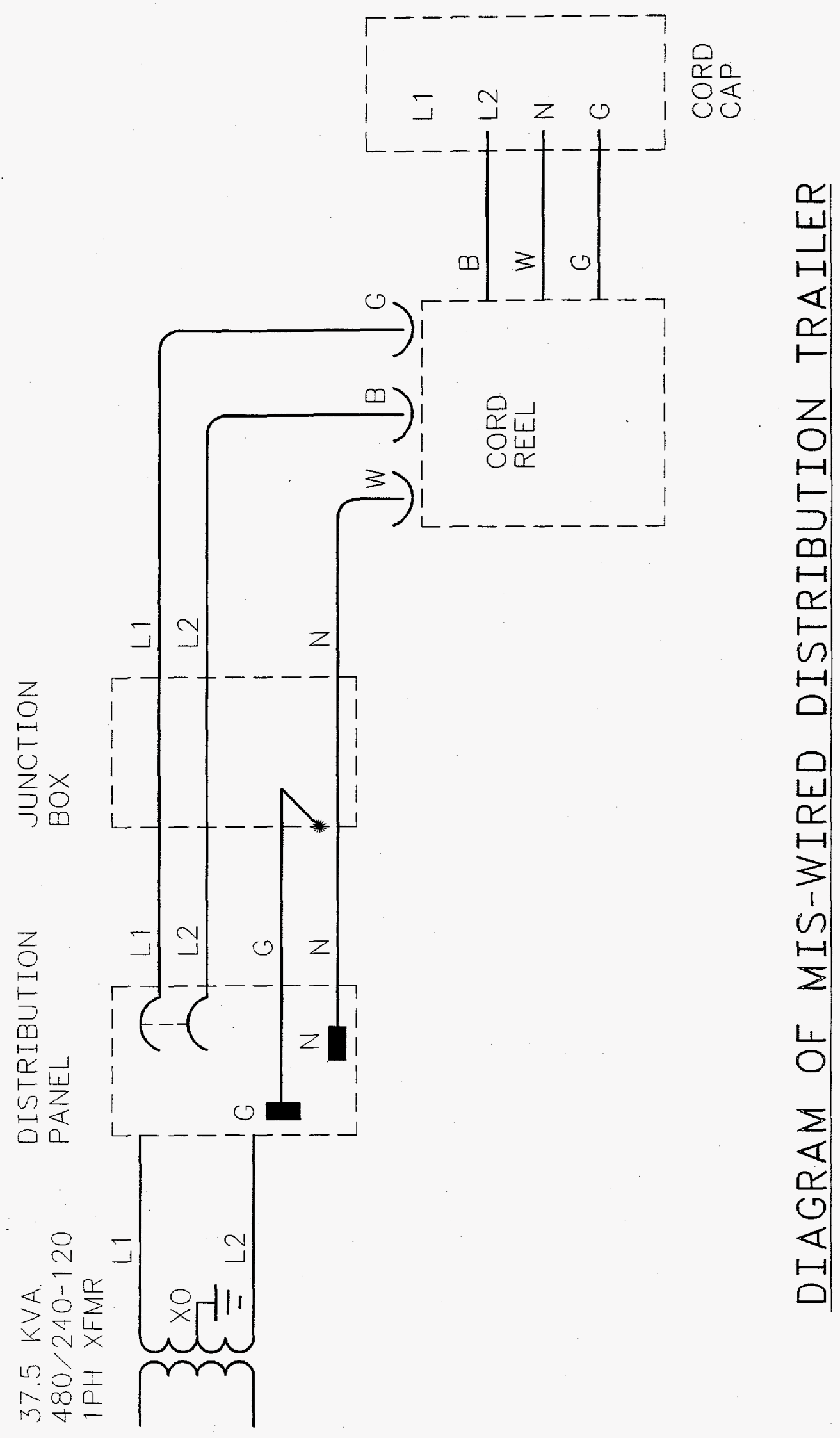


WHC-MR-0505

Page 18

\section{APPENDIX 1}

\section{ENGINEERING PROCESS ASSESSMENT}


From: Equipment Engineering

Phone: $372-0255$ RI-30

Date: May 26, 1995

SUbject: MANAGEMENT ASSESSMENT OF RMCST SUPPORT TRUCKS

To:

\section{J. E. Truax}

$$
\text { ce: }
$$

R2-50
RI-17
S8-05
52-24
ST-81
$57-84$
B4-08
57-12
H5-09
T2-08
R2-50
ST-15
R1 -30
R1 -30
R2-54
E6-38
57-81

Management assessments were performed on May 23 and 24, 1995, on Tank Waste Remediation System (TWRS) electrical equipment currentiy in fabrication. The primary purpose of this assessment was to determine if there is adequate assurance the equipment will meet TWRS needs. The assessment team included personnel from Tank Farm Transition Projects, TWRS Engineering, and ICF KH. The team members were:

$$
\begin{aligned}
& \text { Bill Miller, Chairman, TWRS Engineering } \\
& \text { Judy Burton, Tank Farm Transition Projects } \\
& \text { Keith Carpenter, TWRS Engineering } \\
& \text { Gary Dunford, TWRS Engineering } \\
& \text { Phil Ohl, TWRS Engineering (Part-time) } \\
& \text { Jeff Van Heel, ICF KH (Part-time) }
\end{aligned}
$$

The assessment targeted the engineering process used to develop the designs and deliver the equipment to ensure the fabricated equipment met the needs of TWRS and was appropriate for installation in the Tank farms. Items emphasized during the assessments included: (1) technical bases for the designs; (2) design criteria; (3) design reviews and design verification; (4) Safety bases compliance; and (5) testing.

As a result of the assessment for the Rotary Mode Core Sampie Truck (RMCST) Support Trucks, the following actions and observations were concluded. 
WHC-MR-0505

Page 20

J. E. Truax

$74700-95-W C M-010$

Page 2

Actions Prior to Routine ODerations:

None

Actions for Related Equipment:

None

Observations:

(1) No integrated design criteria was identified for the RMCST system, although there is a Functional Design Criteria for the exhausters.

(2) Complicated systems, such as the RMCST and support systems, should have. a comprehensive test plan that defines all phases of the test program, including test objectives, test conditions, and test activities.

It is the judgment of the assessment team that the RMCST exhausters will meet TWRS needs. We recommend that these components be released from the fabrication shop and included in further testing of the RMCST system.

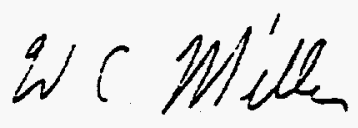

W. C. Miller, Manager

Equipment Engineering

Tar 
From: Equipment Engineering

Phone: $\quad 372-0255$ R1-30

Date: May 26, 1995

Subject: MANAGEMENT ASSESSMENT OF RMCST EXHAUSTERS

To:

$\begin{array}{ll}\text { cc: J. G. Burton } & 58-05 \\ \text { K. E. Carpenter } & 52-24 \\ \text { G. L. Dunford } & 57-81 \\ \text { J. E. Dunks } & L 4-90 \\ \text { L. F. Ermold } & 57-84 \\ \text { D. W. Hamilton } & 57-12 \\ \text { C. E. Hanson } & H 5-09 \\ \text { J. G. Holyoak } & T 2-08 \\ \text { J. L. Lee } & R 2-50 \\ \text { J. W. Lentsch } & 57-15 \\ \text { W. C. Miller } & R 1-30 \\ \text { T. L. Moore } & H 5-09 \\ \text { P. C. OhI } & R 1-30 \\ \text { J. O. Robinson } & H 5-09 \\ \text { J. D. Van Heel } & \text { E6-38 } \\ \text { A. M. Umek } & 57-81 \\ \text { WCM File/LB } & \end{array}$

Management assessments were performed on May 23 and 24, 1995, on Tank Waste Remediation System (TWRS) electrical equipment currently in fabrication. The primary purpose of this assessment was to determine if there is adequata assurance the equipment will meet TWRS needs. The assessment team included personnel from Tank Farm Transition Projects, TWRS Engineering, and ICF KH. The team nembers were:
Bill Miller, Chairman, TwRS Engineering
Judy Burton, Tank Farm Transition Projects
Keith Carpenter, TWRS Engineering
Gary Dunford, TwRS Engineering
Phil Oht, TWRS Engineering (Part-time)
Jeff Van Heel, ICF KH (Part-time)

The assessment targeted the engineering process used to develop the designs and deliver the equipment to ensure the fabricated equipment met the needs of TWRS and was appropriate for installation in the Tank Farms. Items empnasized during the assessments included: (1) technical bases for the designs; (2) design criteria; (3) design reviews and design verification; (4) Safety jases compliance; and (5) testing.

As a result of the assessment for the Rotary Mode Core Sample Truck (RMCST) system exhaustars, the following actions and observations were concluded.

Actions Prior to Release from Shop:

None 
Actions Prior to Release from Shop:

None

Actions Prior to Routine Operations:

(1) Include performance criteria for the support truck testing in the OTP prior to OTP completion.

Actions for Related Equipment:

(2) Evaluate the in-use support truck for NEC compliance issues identified during fabrication shop inspections and implement a corrective action plan. (Currentiy being pursued.)

\section{Observations:}

(1) Resolve pressure relief system design adequacy (identified by Characterization Project personnel in meeting).

(2) No documented design criteria or bases (e.g., System Design Specification), though design is essentialiy the same as the existing support truck.

It is the judgment of the assessment team that the RMCST Support Trucks will meet TWRS needs once the current modifications and the action items listed above are completed. We recommend that these components be released from the fabrication shop and included in further testing of the RMCST system when the current modifications, inspection, and shop testing are completed. This does not alleviate the Cognizant Engineers (system and/or design) from responding to the actions listed. Closure of the action items shall be documented in a letter from the responsible manager to J. E. Truax, with copy coverage to the undersigned.

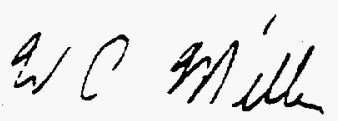

W. C. Miller, Manager

Equipment Engineering

lar 
From: Equipment Engineering

Phone: $372-0255$ Rl-30

REVISED

Date: June 1, 1995

SUbject: MANAGEMENT ASSESSMENT OF SALTWELL PUMPS, JUMPERS, LEAK OETECTORS, AND PUMP RUN-IN

To:

\section{J. E. Truax}

$$
\text { cc: }
$$

V. C. Boyles

J. G. Burton

K. E. Carpenter

G. L. Dunford

D. B. Engleman

L. F. Ermold

J. G. Holyoak

J. L. Lee

W. C. Miller

P. C. OhT

R. E. Raymond

S. J. Sutey

J. D. Van Heel

A. M. Umek

D. D. Wiggins

WCM File/LB

R2-50

RI-49

S8-05

$52-24$

S7-81

RI-49

$57-84$

T2-08

R2-50

RI -30

RI -30

R2-54

RI-49

E6-38

57-81

RI-49

Management assessments were performed on May 23 and 24, 1995, on Tank Waste Remediation System (TWRS) electrical equipment currently in fabrication. The primary purpose of this assessment was to determine if there is adequate assurance the equipment will meet TWRS needs. The assessment team included personnel from Tank Farm Transition Projects, TWRS Engineering, and ICF KH. The team members were:
Bill Miller, Chairman, TWRS Engineering
Judy Burton, Tank Farm Transition Projects
Keith Carpenter, TWRS Engineering
Gary Dunford, TWRS Engineering
Phil Oh1, TWRS Engineering (Part-time)
Jeff Van Heel, ICF KH (Part-time)

The assessment targeted the engineering process used to develop the designs and deliver the equipment to ensure the fabricated equipment met the needs of TWRS and was appropriate for installation in the Tank Farms. Items emphasized during the assessments included: (1) technical bases for the designs; (2) design criteria; (3) design reviews and design verification: (4) safety bases compliance; and (5) testing.

As a result of the assessment for the Saltwell Pumps, Jumpers, Leak Detectors, and Pump Run-in, the following actions and observations were concluded. 
Actions Prior to Release from Shop:

(1) Modify pump systems presentiy in the fabrication shop to resolve NEC compli ance issues.

Actions Prior to Routine Operations:

None

Actions for Related Equioment:

(2) Evaluate if installed pump systems are compliant with the National Electrical Code (NEC). Determine if any non-compliant items present personnel safety hazard.

(3) Inspect and modify spare saltwell equipment for NEC compliance.

Observations:

(1) Dated designs should be reviewed to ensure compliance with current standards and requirements.

(2) The high pressure setpoint.(OSR limit) should be removed or adjusted to a level at or below the test pressure for the pump and jumpers.

(3) The safety basis is dated and needs to be upgraded/modified.

It is the judgment of the assessment team that the Saltwell Pumps, Jumpers, Leak Detectors, and Pump Run-in will meet TWRS needs once the modifications and action $\neq 1$ is completed. We recommend that these components not be released from the fabrication shop until action $\neq 2 \neq 1$ is completed. This does not alleviate the Cognizant Engineers (system and/or design) from responding to all the actions listed. Closure of the action items shall be documented in a letter from the responsible manager to J. E. Truax, with copy coverage to the undersigned.

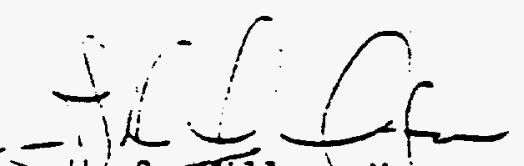

4. E. Tit ler. Manager

Equipment Engineering

iar 
From: Equipment Engineering

Phone: $\quad 372-0255$ R1-30

Memo

Date: June 1, 1995

SUbject: MANAGEMENT ASSESSMENT OF RMCST ELECTRICAL OISTRIBUTION TRAILERS

74700-95-WCM-013

REVISED

To:

\section{J. E. Truax}

ce:
J. G. Burton
K. E. Carpenter
G. L. Dunford
L. F. Ermold
D. W. Hamilton
J. G. Holyoak
B. R. Johns
J. L. Lee
J. W. Lentsch
W. C. Miller
P. C. OhI
R. E. Raymond
J. O. Van Heel
A. M. Umek
58-05
S2-24
$57-81$
57-84
57-12
T2-08
$57-12$
R2-50
$57-15$
R1 -30
RI -30
R2-54
E6-38
57-81

WCM File/LB

R2-50

Management assessments were performed on May 23 and 24, 1995, on Tank Wasta Remediation System (TWRS) electrical equipment currently in fabrication. The primary purpose of this assessment was to determine if there is adequate assurance the equipment will meet TWRS needs. The assessment team included personnel from Tank Farm Transition Projects, TWRS Engineering, and ICF KH. The team members were:
Bill Miller, Chairman, TWRS Engineering
Judy Burton, Tank Farm Transition Projects
Keith Carpenter, TWRS Engineering
Gary Dunford, TwRS Engineering
Phil Oh1, TWRS Engineering (Part-time)
Jeff Van Heel, ICF KH (Part-time)

The assessment targeted the engineering process used to develop the designs and deliver the equipment to ensure the fabricated equipment met the needs of TWRS and was appropriate for installation in the Tank Farms. Items emphasized during the assessments included: (1) technical bases for the designs; (2) design criteria; (3) design reviews and design verification; (4) safety bases compliance; and (5) testing.

As a result of the assessinent for the Rotary Mode Core Sample Truck (RMCST) Electrical Distribution Trailers, the following actions and observations were conciuded.

\section{Actions Prior to Release from Shop:}

None 


\section{Actions Prior to Routine Operations:}

\section{Alote}

(1) Document test procedure with appropriate acceptance criteria, including reasonable ranges and tolerances. (ATP is in preparation, but does not provide ranges for acceptance criteria.)

\section{Actions for Related Equioment:}

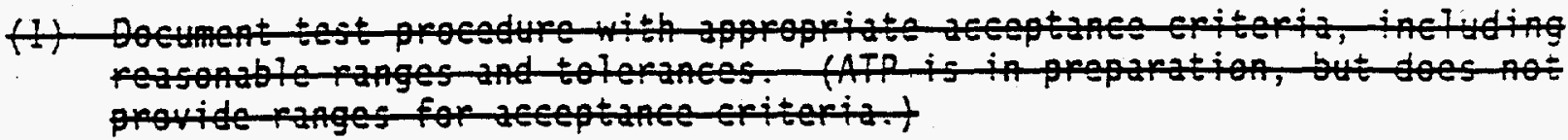

None

\section{Observations:}

(1) Document design criteria for trailers. (Understand that a System Design Specification is being prepared.)

(2) Safety $\mathrm{Class} 4$ designation may not have met procedure requirements effective at the time this equipment was designed, and did not address personnel safety hazards.

(3) Cognizant Manager should provide an independent one-over-one approval of design documents.

It is the judgment of the assessment team that the RMCST Electrical Distribution Trailers will meet TWRS needs once the equipment is properly modified and the above action item is completed. We recomnend that these components be released from the fabrication shop when the modifications are completed, inspected, and shop tested. NEC compliance design issues must be resolved before release from the shop. This does not alleviate the Cognizant Engineers (system and/or design) from responding to the action listed. Closure of the action item shall be documented in a letter from the responsible manager to J. E. Truax, with copy coverage to the undersigned.

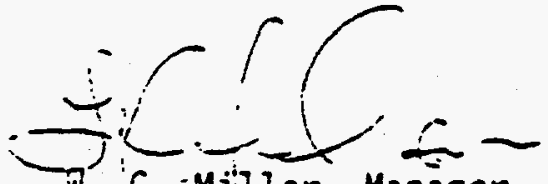

W. C. Minl ler, Manäger

Equipment Engineering

$1 \mathrm{ar}$ 
From: Equipment Engineering

Phone: $\quad 372-0255$ R1-30

Date: May 26, 1995

Subject: MANAGEMENT ASSESSMENT OF DECANT PUMP CONTROL PANEL AND SUSPENDED SOLID MONITOR

To:

J. E. Truax R2-50

$\begin{array}{ll}\text { CC: D. E. Ball } & 54-58 \\ \text { J. G. Burton } & 58-05 \\ \text { K. E. Carpenter } & 52-24 \\ \text { G. L. Dunford } & 57-81 \\ \text { L. F. Ermold } & 57-84 \\ \text { J. S. Garfield } & H 5-49 \\ \text { J. G. Holyoak } & T 2-08 \\ \text { J. L. Lee } & R 2-50 \\ \text { G. T. Maclean } & H 5-49 \\ \text { W. C. Miller } & R 1-30 \\ \text { P. C. OhI } & R 1-30 \\ \text { R. E. Raymond } & R 2-54 \\ \text { S. G. Romero } & 52-47 \\ \text { T. W. Staehr } & R 3-27 \\ \text { J. A. Swenson } & H 5-49 \\ \text { J. O. Van Heel } & \text { E6-38 } \\ \text { A. M. Umek } & 57-81 \\ \text { WCM File/LB } & \end{array}$

Management assessments were performed on May 23 and 24, 1995, on Tank Waste Remediation System (TWRS) electrical equipment currently in fabrication. The primary purpose of this assessment was to determine if there is adequate assurance the equipment will meet TWRS needs. The assessment team included personnel from Tank Farm Transition Projects, TWRS Engineering, and ICF KH. The team nembers were:

Bill Miller, Chairman, TWRS Engineering

Judy Burton, Tank Farm Transition Projects

Keith Carpenter, TWRS Engineering

Gary Dunford. TWRS Engineering

Phil Ohi, TWRS Engineering (Part-time)

Jeff Van Heel, ICF KH (Part-time)

The assessment targeted the engineering process used to develop the designs and deliver the equipment to ensure the fabricated equipment met the needs of TWRS and was appropriate for installation in the Tank Farms. Items smohasized during the assessments included: (1) technical bases for the designs; (2) design criteria; (3) design reviews and design verification; (4) Safety bases compliance; and (5) testing.

As a result of the assessment for the Decant Pump Control Panel and Suspended Solid Monitor, the following actions and observations were concluded. 
Actions Prior to Release from Shop:

(1) Need to verify that current modifications have not negated previous acceptance tests.

Actions Prior to Routine Operations:

None

Actions for Related Equipment:

None

Observations:

(1) Design eriteria were not specifically documented, though criteria were given in a letter of instruction to the design engineer.

(2) Need to identify a Test Director from Tank Farm Transition Projects.

It is the judgment of the assessment team that the Decant Pump Controi Panel and Suspended Solid Monitor will meet TWRS needs once the modifications and action item are completed. We recommend that these components be released from the fabrication shop when the modifications are completed, inspected, and shop tested, and the action item is completed. Closure of the action item shall be documented in a letter from the responsibie manager to

J. E. Truax, with copy coverage to the undersigned.

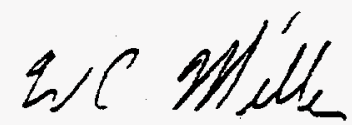

W. C. Miller, Manager

Equipment Engineering

Tar 
From: Equipment Engineering

Phone: 372-0255 R1-30

Date: May 25, 1995

SUbject: MANAGEMENT ASSESSMENT OF DENSITOMETER ASSEMBLIES

To:

J. E. Truax R2-50

$\begin{array}{ll}\text { cc: J. G. Burton } & 58-05 \\ \text { K. G. Carothers } & \text { RI-51 } \\ \text { K. E. Carpenter } & 52-24 \\ \text { J. L. Dowell } & E 6-21 \\ \text { G. L. Dunford } & 57-81 \\ \text { L. F. Ermold } & 57-84 \\ \text { G. N. Hanson } & 55-05 \\ \text { J. L. Lee } & R 2-50 \\ \text { W. C. Miller } & R 1-30 \\ \text { R. S. Nicholson } & 55-05 \\ \text { P. C. Ohl } & R 1-30 \\ \text { R. E. Raymond } & R 2-54 \\ \text { J. D. Van Heel } & E 5-38 \\ \text { A. M. Umek } & 5 T-81 \\ \text { WCM File/LB } & \end{array}$

Management assessments were performed on May 23 and 24, 1995, on Tank Waste Remediation System (TWRS) electrical equipment currently in fabrication. The primary purpose of this assessment was to determine if there is adequate assurance the equipment will meet TWRS needs. The assessment team included personnel from Tank Farm Transition Projects, TWRS Engineering, and ICF KH. The team members were:

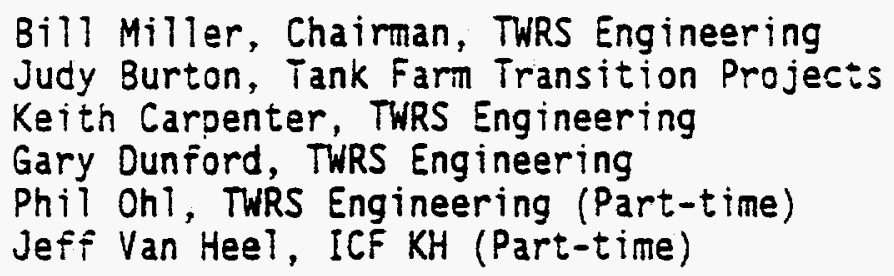

The assessment targeted the engineering process used to develop the designs and deliver the equipment to ensure the fabricated equipment met the needs of TWRS and was appropriate for installation in the Tank Farms. Items emphasized during the assessments included: (1) technicai bases for the designs; (2) design criteria; (3) design reviews and design verification; (4) safety bases compliance; and (5) testing.

As a result of the assessment for the Densitometer Assembites, the following actions and ooservations were concluded.

Actions Prior to Release from Shoo:

None 
Page 2

Actions Prior to Routine Operations:

(1) Document acceptance criteria, including ranges and tolerances, for critical parameters in the Operability Test Procsdure.

\section{Actions for Related Equipment:}

None

Observations:

(1) No documented design criteria, al though they are being addressed in acceptance test documentation (to be issued).

It is the judgment of the assessment team that the Densitometer Assemblies will meet TWRS needs once the fabrications are completed and the above action item is completed. We recommend that these components be released from the fabrication shop when the assembly fabrications are completed and inspected. This does not alleviate the Cognizant Engineers (system and/or design) from responding to the action listed. Closure of the action item shall be documented in a letter from the responsible manager to J. E. Truax, with copy coverage to the undersigned.

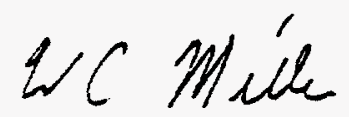

w. C. Miller, Manager

Equipment Engineering

lar 
From: Equipment Engineering

Memo

Phone: $\quad 372-0255$ R1-30

Date: $\quad$ May 26, 1995

Subject: MANAGEMENT ASSESSMENT OF AN-107 CAUSTIC INJECTION PUMP TRANSDUCER

To:

$\begin{array}{ll}\text { J. E. Truax } & R 2-50 \\ \text { cc: J. G. Burton } & 58-05 \\ \text { K. G. Carothers } & R 1-51 \\ \text { K. E. Carpenter } & 52-24 \\ \text { G. L. Dunford } & 57-81 \\ \text { L. F. Ermold } & 57-84 \\ \text { R. L. Hand } & S 4-53 \\ \text { G. N. Hanson } & 55-05 \\ \text { J. G. Holyoak } & T 2-08 \\ \text { J. Langdon } & 52-02 \\ \text { J. L. Lee } & R 2-50 \\ \text { W. C. Miller } & R 1-30 \\ \text { R. S. Nicholson } & S 5-05 \\ \text { P. C. Ohl } & R 1-30 \\ \text { R. E. Raymond } & R 2-54 \\ \text { G. E. Rensink } & S 2-24 \\ \text { J. D. Van Heel } & E 6-38 \\ \text { A. M. Umek } & S 7-81 \\ \text { WCM File/LB } & \end{array}$

Management assessments were performed on May 23 and 24, 1995, on Tank Waste Remediation System (TWRS) electrical equipment currentiy in fabrication. The primary purpose of this assessment was to determine if there is adequate assurance the equipment will meet TWRS needs. The assessment team included personnel from Tank Farm Transition Projects, TWRS Engineering, and ICF KH. The team nembers were:
Bill Miller, Chairman, TWRS Engineering
Judy Burton, Tank Farm Transition Projects
Keith Carpenter, TWRS Engineering
Gary Dunford, TWRS Engineering
Phil Ohl, TWRS Engineering (Part-time)
Jeff Van Heel, ICF KH (Part-time)

The assessment targeted the engineering process used to develop the designs and deliver the equipment to ensure the fabricated equipment met the needs of TWRS and was appropriate for installation in the Tank Farms. Items emphasized during the assessinents included: (1) technical bases for the designs; (2) design criteria; (3) design reviews and design verification; (4) sarety bases compliance; and (5) testing.

As a result of the assessment for the AN-107 Caustic Injection Pump Transducer, the following actions and observations were concluded. 
Page 2

\section{Actions Prior to Release from Shop:}

None

Actions Prior to Routine Operations:

None

Actions for Related Equipment:

None

Observations:

(1) No design criteria are documented for the transducers. These transducers will be used in a demonstration test of the best availabie technology to determine field suitability.

It is the judgment of the assessment team that the AN-107 Caustic injection Pump Transducer will meet TWRS needs when the modifications are completed. We recommend that these components be released from the fabrication shop when the modifications are completed and inspected.<smiles>C=C(C)C(C)C#CC</smiles>

W. C. Miller, Manager Equipment Engineering

$\operatorname{Tar}$ 
From: Equipment Engineering

74700-95-WCM-017

Phone: $\quad 372-0255$ R1-30

Date: May 26, 1995

SUbject: MANAGEMENT ASSESSMENT OF 244-A SPARE PUMP MODIFICATION AND RUN-IN

To:

J. E. Truax R2-50

$\begin{array}{ll}\text { cC: J. G. Burton } & 58-05 \\ \text { K. E. Carpenter } & 52-24 \\ \text { G. L. Dunford } & 57-81 \\ \text { L. F. Ermold } & 57-84 \\ \text { G. N. Hanson } & 55-05 \\ \text { J. G. Holyoak } & T 2-08 \\ \text { J. L. Lee } & R 2-50 \\ \text { W. C. Miller } & R 1-30 \\ \text { R. S. Nicholson } & 55-05 \\ \text { P. C. Ohi } & R 1-30 \\ \text { J. O. Van Heel } & E 6-38 \\ \text { A. M. Umek } & 57-81 \\ \text { T. L. Warnick } & 55-01 \\ \text { J. H. Wicks } & 55-07 \\ \text { WCM File/LB } & \end{array}$

Management assessments were performed on May 23 and 24, 1995, on Tank Waste Remediation System (TWRS) electrical equipment currently in fabrication.

The primary purpose of this assessment was to determine if there is adequate assurance the equipment will meet TWRS needs. The assessment team included personnel from Tank Farm Transition Projects, TWRS Engineering, and ICF KH. The team members were:

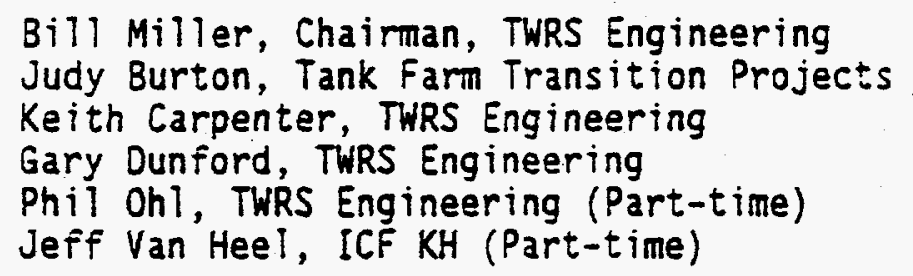

The assessment targeted the engineering process used to develop the designs and deliver the equipment to ensure the fabricated equipment met the needs of TWRS and was appropriate for installation in the Tank Farms. Items emphasized during the assessments included: (1) technical bases for the designs; (2) design criteria; (3) design reviews and design verification; (4) safety bases compliance; and (5) testing.

As a result of the assessment for the 244-A Spare Pump Modification and Run-In, the following actions and observations were concluded.

Actions Prior to Release from Shoo:

None 
Actions Prior to Routine Operations:

(1) Add a blank connector to the pump flush line prior to storage of the pump.

\section{Actions for Related Equipment:}

None

\section{Observations:}

(1) Addition of a pump flush line is not documented or justified in the design criteria or design bases.

It is the judgment of the assessment team that the 244-A Spare Pump Modification and Run-in will meet TWRS needs once the modifications and action items are completed. We recommend that these components be released from the fabrication shop following completion of the modifications, inspection, testing, and the action item. Closure of the action item shall be documented in a letter from the responsible manager to J. E. Truax, with copy coverage to the undersigned.

\section{\&C Milln}

W. C. Miller, Manager

Equipment Engineering

$\operatorname{lar}$ 
Phone: 372-0255 R1-30

Date: May 26, 1995

Subject: MANAGEMENT ASSESSMENT OF AN-107 CAUSTIC MIXING SKIO
To:
J. E. Truax
R2-50

$\begin{array}{ll}\text { CC: J. G. Burton } & 58-05 \\ \text { K. G. Carothers } & R 1-51 \\ \text { K. E. Carpenter } & 52-24 \\ \text { G. L. Dunford } & 57-81 \\ \text { W. Eilis } & 52-02 \\ \text { L. F. Ermold } & 57-84 \\ \text { G. N. Hanson } & 55-05 \\ \text { J. G. Holyoak } & 52-08 \\ \text { J. L. Lee } & R 2-50 \\ \text { W. C. Miller } & R 1-30 \\ \text { R. S. Nicholson } & 55-05 \\ \text { P. C. OhI } & R 1-30 \\ \text { G. P. Paintner } & 52-02 \\ \text { J. D. Van Heel } & \text { ES-38 } \\ \text { A. M. Umek } & 57-81 \\ \text { WCM File/LB } & \end{array}$

Management assessments were performed on May 23 and 24, 1995, on Tank Waste Remediation System (TWRS) electrical equipment currentiy in fabrication. The primary purpose of this assessment was to determine if there is adequate assurance the equipment will meet TWRS needs. The assessment team included personnel from Tank farm Transition Projects, TWRS Engineering, and ICF KH. The team nembers were:

Bill Miller, Chairman, TWRS Engineering Judy Burton, Tank Farm Transition Projects

Keith Carpenter, TWRS Engineering

Gary Dunford, TwRS Engineering

Phil Oh1, TWRS Engineering (Part-time)

Jeff Van Heel, ICF KH (Part-time)

The assessment targeted the engineering process used to develop the designs and deliver the equipment to ensure the fabricated equipment met the needs of TWRS and. was appropriate for installation in the Tank Farms. Items emphasized during the assessments included: (1) technical bases for the designs; (2) design criteria; (3) design reviews and design verification; (4) safety bases compliance; and (5) testing.

As a result of the assessment for the AN-107 Caustic Mixing Skid, the following actions and observations were concluded.

Actions Prior :o Release from Shoo:

None 
WHC-MR-0505

Page 36

J. E. Truax

74700-95-WCM-018

Page 2

Actions Prior to Routine Operations:

None

Actions for Related Equipment:

None

Observations:

(1) Ensure appropriate testing is performed to verify that the latest upgrades have not invalidated previous testing.

It is the judgment of the assessment team that the AN-107 Caustic Mixing Skid will meet TWRS needs when the upgrades are completed. We recommend that these components be released from the fabrication shop when the upgrades are completed and inspected.

QC M Mile

W. C. Miller, Manager Equipment Engineering

$\operatorname{lar}$ 
WHC-MR-0505

Page 37

\section{APPENDIX 2}

\section{DESIGN REVIEW RESULTS}




\section{NEC COMMENT RECORD}

NUMBER: 3370

DATE: November 5, 1993

KEYWORD: NEC Inspection

TO: JE Dunks

PHONE: $376-8793$

INTERPRETIVE AUTHORITY: CM Monasmith

PHONE: $376-8109$

BUILDING NUMBER: Rotary Mode Core Drill Exhauster

PROJECT NUMBER: N/A

REFERENCE CODE/STANDARD/REGULATION: NEC

REQUEST RECEIVED VIA: SITE VISIT [X] TELE-CONV. [] OTHER

CONDITION: Evaluate Rotary Mode Core Drill Exhauster for NEC compliance.

REPLY ISSUED VIA: DISCUSSION ON SITE [X] TELE-CONV. [] cc:MAIL [X] OTHER

COMMENT: The Rotary Mode Core Drill Exhauster is mobile unit was evaluated for NEC compliance with appropriate NEC wiring methods, grounding and overcurrent

protection. It was noted that the workmanship was good and that no NEC concerns were observed.

CORRECTIVE ACTION REQUIRED: None. Unit is approved for connection to

electrical service. 


\section{NEC COMMENT RECORD}

NUMBER: 3564

DATE: March 13, 1995

KEYWORD: IMMERSION HEATER

TO: LA Mercer

PHONE: $373-2477$

INTERPRETIVE AUTHORITY: CM Monasmith

PHONE: $376-8109$

BUILDING NUMBER: N/A

PROJECT NUMBER: N/A

REFERENCE CODE/STANDARD/REGULATION: NEC, UL Directories

\section{REQUEST RECEIVED VIA: SITE VISIT $[X]$ TELE-CONV. [ ] OTHER}

CONDITION: Commercial dishwasher immersion heaters are to be installed in $\mathbf{5 5}$ gallon drums for liquid heating. The units are installed upside down. IS this within the UL Listing?

REPLY ISSUED VIA: DISCUSSION ON SITE $[X]$ TELE-CONV. [ ] cC:MAIL $[X]$ OTHER

COMMENT: No. However, the units may be used as installed with the following caveats. Installing the heaters upside down puts the temperature limiting sensor below the elements. If a low liquid level exists the top elements may not be covered with 1iquid. this would allow the elements to overheat and fail dramatically. A liquid level control has been installed. This liquid level control should prevent element damage from low liquid.

The enclosure is labeled "TOP". The enclosure is constructed with NEMA 4 features, although it is not Listed as a NEMA 4 enclosure. One of the type requirements is that penetrations for conduits and wiring are located below energized electrical parts. This is adequately compensated for by RTV sealing of the conduit openings.

CORRECTIVE ACTION REQUIRED: None. However it should be noted that more careful selection of components would have allowed fabrication of this equipment with UL Listed components used as the manufacturer designed them to be used and without special investigation of the Listing and Labeling requirements. 


\section{NEC COMMENT RECORD}

NUMBER: 3565

DATE: March 13, 1995

KEYWORD: Enclosed switches

TO: LA Mercer

PHONE: 373-2477

INTERPRETIVE AUTHORITY: CM Monasmith

PHONE: $376-8109$

BUILDING NUMBER: N/A

PROJECT NUMBER: N/A

REFERENCE CODE/STANDARD/REGULATION: NEC $380-3,110-3$ (b)

REQUEST RECEIVED VIA: SITE VISIT [X] TELE-CONV. [] OTHER

CONDITION: A 60 amp enclosed fused switch is to be modified by installing a circuit breaker on a DIN rail inside the enclosure. Does this violate the UL Listing?

REPLY ISSUED VIA: DISCUSSION ON SITE [X] TELE-CONV. [ ] cC:MAIL $[X]$ OTHER

COMMENT: Yes. NEC Article 380-3 allows only the overcurrent device associated with that switch to be within the switch enclosure. Additionally the UL Listing directory for enclosed switches requires that all switches be operable from outside the enclosure.

CORRECTIVE ACTION REQUIRED: Locate additional overcurrent protection in a separate enclosure. 


\section{NEC COMMENT RECORD}

NUMBER: 3575

DATE: Apri1 14, 1995

KEYWORD: Caustic Skid

TO: JD Van Heel

PHONE: $376-9112$

INTERPRETIVE AUTHORITY: CM Monasmith

PHONE: $376-8109$

BUILDING NUMBER: 241-AN

PROJECT NUMBER: N/A

REFERENCE CODE/STANDARD/REGULATION: NEC

\section{RQUEST RECEIVED VIA: 1p14.4VE\$4T48T\$ITETELE-CONV. [] OTHER}

CONDITION: Design Review of Caustic Addition Pump Skid for NEC compliance.

\section{REPLY ISSUED VIA: DISCUSSION ON SITE [] TELE-CONV. [] cc:MAIL [X] OTHER}

COMMENT: Terminal strips were evaluated for suitability for field wiring, enclosures and control devices were al so evaluated for NRTL recognition. The Electrical Wiring Diagram on H-2-85351 shows a variable speed drive for the 2 hp pump motor. This drive and the associated disconnect switch are not part of the skid and could not be evaluated.

Motor overload protection is provided by the manual motor starter. However, the short circuit and ground fault protection is provided in the field by the motor disconnect switch and could not be evaluated.

Drawing H-2-85351 shows circuit EDS-DP-108 ckt 7 providing 480 volts to the pump motor. Al so circuit EDS-DP-109 ckt 5 provides 120 volts to TB2 for convenience loads. It is not sufficiently clear that these circuits are different voltages.

EDS-DP-108 ckt 7 is not clearly described on these drawings. Does this circuit provide protection as required by NEC Article 430-54?

CORRECTIVE ACTION REQUIRED: Provide evidence of motor short circuit protection before caustic pump skid is energized. This is very important if shop functional testing is undertaken (testing the pump without attaching the pump to the skid support building). Verify components in other buildings are compatible and that they provide the level of protection required for this equipment. 


\section{NEC COMMENT RECORD}

NUMBER: 3580

DATE: Apri1 28, 1995

KEYWORD: Saltwell Jet Pump

TO: JD van Heel

PHONE: 376-9112

INTERPRETIVE AUTHORITY: CM Monasmith

PHONE: $376-8109$

BUILDING NUMBER: N/A

PROJECT NUMBER: N/A

REFERENCE CODE/STANDARD/REGULATION: NEC

\section{REQUEST RECEIVED VIA: SITE VISIT [] TELE-CONV. [] OTHER}

CONDITION: Provide desjgn review of saltwel1 jet pump for NEC compliance.

REPLY ISSUED VIA: DISCUSSION ON SITE [] TELE-CONV. [] cc:MAIL [X] OTHER

COMMENT: 1. Electric motor indicated on Drawing H-2-93990 sheet 2 is not described on material list on sheet 1. ECN 618348 provides motor data, except for motor horsepower. Motor protection and installation can be completed from the information provided, however, motor horsepower is typically included with other nameplate information.

2. Motor overload and short circuit protection is provided by equipment not identified in this design. Appropriateness of motor protection could not be evaluated.

\section{CORRECTIVE ACTION REQUIRED:}

Item 1. No action is required for NEC compliance.

Item 2. Verify motor overload and short circuit protection before field installation is completed. 


\section{NEC COMMENT RECORD}

NUMBER: 3581

DATE: Apri1, 28, 1995

KEYWORD: Densitometer

TO: JD van Heel

PHONE: 376-9112

INTERPRETIVE AUTHORITY: CM Monasmith

PHONE: $376-8109$

BUILDING NUMBER: N/A

PROJECT NUMBER: N/A

REFERENCE CODE/STANDARD/REGULATION: NEC

REQUEST RECEIVED VIA: SITE VISIT [] TELE-CONV. [] OTHER

CONDITION: Evaluate work package \# $2 \mathrm{H} 9500279 \mathrm{~F}$ for NEC compliance

REPLY ISSUED VIA: DISCUSSION ON SITE [] TELE-CONV. [] cC:MAIL [X] OTHER

COMMENT: 1. Drawing H-2-824486 sheet 1. Material List calls for a Littlefuse 357001 fuse holder to be installed in a cast outlet box. This type if fuse holder has through bolt hole for mounting. There is no direction on how to mount the fuse holder. drilling the box will defeat the raintight UL listing.

CORRECTIVE ACTION REQUIRED: 1. Verify a fuseholder mounting method that does not penetrate the box wall. An in-line fuseholder may be more appropriate. 
NUMBER: 3582

DATE: Apri1 28, 1995

KEYWORD: Saltwell Jumper

TO: JD van Heel

PHONE: 376-9112

INTERPRETIVE AUTHORITY: CM Monasmith

PHONE: $376-8109$

BUILDING NUMBER: N/A

PROJECT NUMBER: W/P 2H9500259F

REFERENCE CODE/STANDARD/REGULATION: NEC

REQUEST RECEIVED VIA: SITE VISIT [] TELE-CONV. [ ] OTHER

CONDITION: Evaluate design for NEC compliance.

REPLY ISSUED VIA: DISCUSSION ON SITE [] TELE-CONV. [] cc:MAIL [X] OTHER

\section{COMMENT:}

1. Open wiring method is not per NEC Chapter 3 wiring methods. NEC Article 427-3

2. Design does not specify warning signs as required by NEC Article 427-13.

3. Non-heating leads are to be located inside thermal insulation (ECN \# 154967) the non-heating leads are not protected where they emerge from the thermal insulation

as required by NEC Article 427-18(b).

4. Original design shows splices and junction outside of the thermal insulation that are not protected by boxes as required by NEC Article 427-19(b).

5. Non-heating leads, where exposed are not marked within three inches of thermal insulation as required by NEC Article 427-20.

6. Disconnecting means meeting the requirements of NEC Article 427-55 has not been identified.

\section{CORRECTIVE ACTION REQUIRED:}

1. Use wiring method allowed in Articles 300 and 427.

2. Provide warning signs as required. (available from heat race manufacturer.)

3. Provide required protection for non-heating leads.

4. Provide junction and splice boxes where required.

5. Provide marking. (also available from heat trace manufacturer)

6. Verify disconnecting means is provided with lock-out features before field installation of jumper. 


\section{NEC COMMENT RECORD}

NUMBER: 3583

DATE: May 22, 1995

KEYWORD: DECANT PUMP

TO: JD Van Heel

PHONE: $376-9112$

INTERPRETIVE AUTHORITY: CM Monasmith

PHONE: $376-8109$

BUILDING NUMBER: N/A

PROJECT NUMBER: Work Package 2H9401113-F

REFERENCE CODE/STANDARD/REGULATION: NEC

REQUEST RECEIVED VIA: SITE VISIT [] TELE-CONV. [ ] OTHER

CONDITION: Provide design review to confirm NEC compliance

REPLY ISSUED VIA: DISCUSSION ON SITE [] TELE-CONV. [] cc:MAIL [X] OTHER

COMMENT: Sample components were verified as UL Listed. UL verification was not for $100 \%$ of components. No discrepancies in either the NEC or use of Listed equipment was noticed.

CORRECTIVE ACTION REQUIRED: None. 


\section{NEC COMMENT RECORD}

\section{NUMBER: 3581}

DATE: Apri1, 28, 1995

KEYWORD: Densitometer

JD van Heel

PHONE: $376-9112$

INTERPRETIVE AUTHORITY: CM Monasmith

PHONE: $376-8109$

BUILDING NUMBER: N/A

PROJECT NUMBER: N/A

REFERENCE CODE/STANDARD/REGULATION: NEC

\section{REQUEST RECEIVED VIA: SITE VISIT [] TELE-CONV. [ ] OTHER}

CONDITION: Evaluate work package \# $2 \mathrm{H} 9500279 \mathrm{~F}$ for NEC compliance

REPLY ISSUED VIA: DISCUSSION ON SITE [] TELE-CONV. [ ] cc:MAIL [X] OTHER

COMMENT: 1. Drawing H-2-824486 sheet 1. Material List calls for a Littlefuse 357001 fuse holder to be installed in a cast outlet box. This type if fuse holder has through bolt hole for mounting. There is no direction on how to mount the fuse holder. drilling the box will defeat the raintight UL listing.

CORRECTIVE ACTION REQUIRED: 1 . Verify a fuseholder mounting method that does not penetrate the box wall. An in-line fuseholder may be more appropriate. 


\section{NEC COMMENT RECORD}

NUMBER: 3580

DATE: Apri1 28, 1995

KEYWORD: Saltwell Jet Pump

JD van Heel

PHONE: 376-9112

INTERPRETIVE AUTHORITY: CM Monasmith

PHONE: $376-8109$

BUILDING NUMBER: N/A

PROJECT NUMBER: N/A

REFERENCE CODE/STANDARD/REGULATION: NEC

\section{REQUEST RECEIVED VIA: SITE VISIT [] TELE-CONV. [] OTHER}

CONDITION: Provide design review of saltwell jet pump for NEC compliance.

\section{REPLY ISSUED VIA: DISCUSSION ON SITE [] TELE-CONV. [] cc:MAIL [X]} OTHER

COMMENT: 1. Electric motor indicated on Drawing H-2-93990 sheet 2 is not described on material list on sheet 1. ECN 618348 provides motor data, except for motor horsepower. Motor protection and installation can be completed from the information provided, however, motor horsepower is typically included with other nameplate information.

2. Motor overload and short circuit protection is provided by equipment not identified in this design. Appropriateness of motor protection could not be evaluated.

\section{CORRECTIVE ACTION REQUIRED:}

Item 1. No action is required for NEC compliance.

Item 2. Verify motor overload and short circuit protection before field installation is completed. 


\section{NEC COMMENT RECORD}

NUMBER: 3582

DATE: April 28, 1995

KEYWORD: Saltwell Jumper

JD van Heel

PHONE: $376-9112$

INTERPRETIVE AUTHORITY: CM Monasmith

PHONE: $376-8109$

BUILDING NUMBER: N/A

PROJECT NUMBER: W/P 2H9500259F, 2H9500258F, 2H9500257F

REFERENCE CODE/STANDARD/REGULATION: NEC

\section{REQUEST RECEIVED VIA: SITE VISIT [] TELE-CONV. [] OTHER}

CONDITION: Evaluate design for NEC compliance.

\section{REPLY ISSUED VIA: DISCUSSION ON SITE [] TELE-CONV. [] cc:MAIL [X]} OTHER

\section{COMMENT:}

1. Open wiring method is not per NEC Chapter 3 wiring methods. NEC Article 427-3

2. Design does not specify warning signs as required by NEC Article 427-13.

3. Non-heating leads are to be located inside thermal insulation (ECN \# 154967) the non-heating leads are not protected where they emerge from the thermal insulation

as required by NEC Article 427-18(b).

4. Original design shows splices and junction outside of the thermal insulation that are not protected by boxes as required by NEC Article 427-19(b).

5. Non-heating leads, where exposed are not marked within three inches of thermal insulation as required by NEC Article 427-20.

6. Disconnecting means meeting the requirements of NEC Article 427-55 has not been identified.

\section{CORRECTIVE ACTION REQUIRED:}

1. Use wiring method allowed in Articles 300 and 427.

2. Provide warning signs as required. (available from heat race manufacturer.)

3. Provide required protection for non-heating leads.

4. Provide junction and splice boxes where required.

5. Provide marking. (also available from heat trace manufacturer)

6. Verify disconnecting means is provided with lock-out features before field installation of jumper. 


\begin{tabular}{|c|c|c|}
\hline \multirow{2}{*}{ REVIEW COMMENT RECORD (RCR) } & $\begin{array}{l}\text { 1. Date } \\
\text { June 5, 1995 }\end{array}$ & $\begin{array}{c}\text { 2. Review No. } \\
3590 . \text { NEC }\end{array}$ \\
\cline { 2 - 4 } & $\begin{array}{c}\text { 3. Project No. } \\
\text { W/P 2H9500059F }\end{array}$ & $\begin{array}{l}\text { 4. Page } \\
1 \text { of } 2\end{array}$ \\
\hline
\end{tabular}

\begin{tabular}{|c|c|c|c|c|}
\hline $\begin{array}{l}\text { 5. Document Number(s)/Title(s) } \\
\text { Work Package } 2 \mathrm{H} 9500059 \mathrm{~F} / \text { Portable } \\
\text { Leak Detector Assembly }\end{array}$ & $\begin{array}{l}\text { 6. Program/Project/ } \\
\text { Building Number }\end{array}$ & $\begin{array}{l}\text { 7. Reviewer } \\
\text { CM Monasmith }\end{array}$ & $\begin{array}{l}\text { 8. Organization/Group } \\
\text { ICF-KH/Electrical } \\
\text { Engineering }\end{array}$ & $\begin{array}{l}\text { 9. Location/Phone } \\
\text { TCPC 2-89/ } \\
376-8109\end{array}$ \\
\hline
\end{tabular}

17. Comment Submittal Approval:

Organization Manager (Optional)
10. Agreement with indicated comment disposition(s)

Reviewer/Point of Contact

11. CLOSED

Reviewer/Point of Contact

Date

Author/Originator

\begin{tabular}{|c|c|c|c|c|}
\hline $\begin{array}{l}12 . \\
1 \text { tem }\end{array}$ & $\begin{array}{l}\text { 13. Comment(s)/Discrepancy(s) (Provide technical justification for the } \\
\text { comment and detailed recommendation of the action required to correct/ } \\
\text { resolve the discrepancy/problem indicated.) }\end{array}$ & $\begin{array}{l}14 . \\
\text { Hold } \\
\text { Point }\end{array}$ & 15. Disposition (Provide justification if NOT accepted.) & $\begin{array}{l}16 . \\
\text { Status }\end{array}$ \\
\hline 1. & $\begin{array}{l}\text { Drawing H-2-85196 sheet } 2 \text { and sheet } 5 \text { (parts } 1 \text { ist). } \\
\text { There is an inconsistency between component } \\
\text { specifications. A NEMA } 4 \text { outdoor weatherproof } \\
\text { enclosure is specified but weatherproof cord cap } \\
\text { (item \#37 is not specified). }\end{array}$ & & & \\
\hline 3. & $\begin{array}{l}\text { Drawing } \mathrm{H}-2-85196 \text { sheet } 2 \text { and sheet } 5 \text { (parts } 1 \text { ist). } \\
\text { Item } \# 29 \text { is identified as a hub, any grade. A } \\
\text { weatherproof hub, such as Meyer's hub is required to } \\
\text { maintain the integrity of the NEMA } 4 \text { enclosure. } \\
\text { This is a violation of NEC Article } 110-3 \text { (b) }\end{array}$ & & 6 & \\
\hline
\end{tabular}




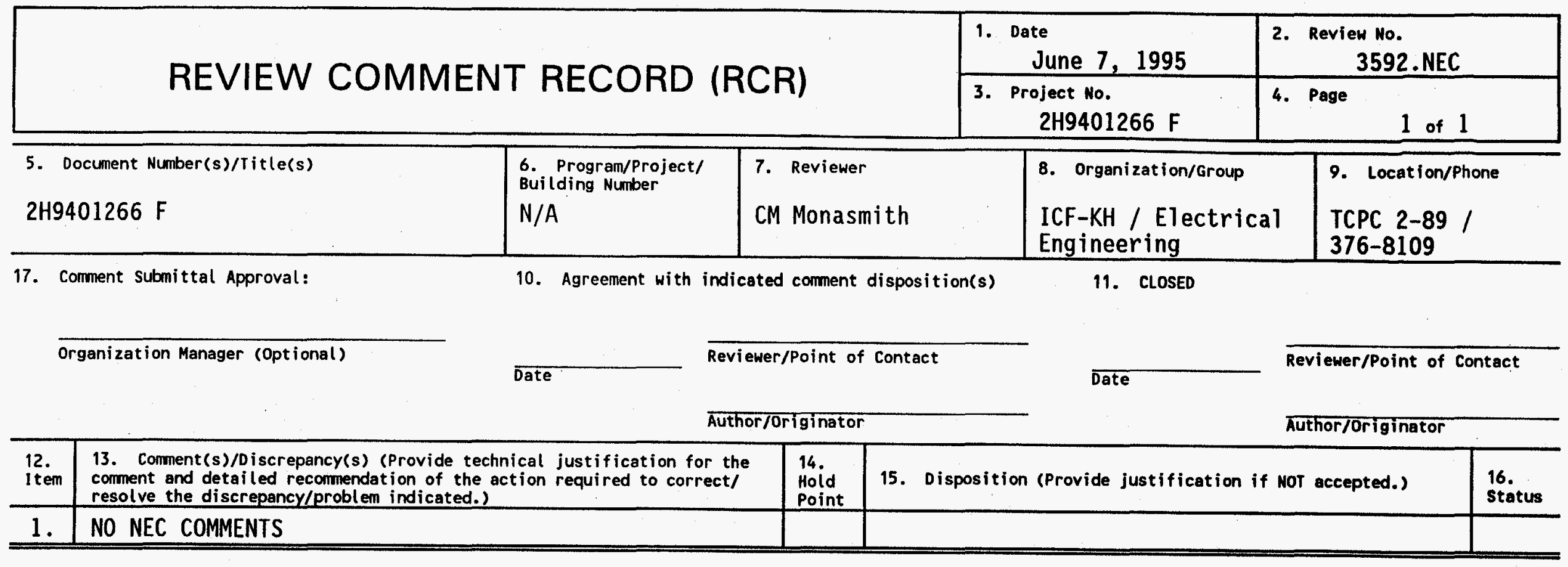


WHC-MR-0505

Page 51

\section{APPENDIX 3}

FIELD SURVEY RESULTS 
NEC INSPECTION RECORD

\begin{tabular}{|l|lc|c||}
\hline $\begin{array}{l}\text { Inspection Number } \\
\text { ICFKH-4336 }\end{array}$ & $\begin{array}{l}\text { Requestor } \\
\text { Jeff Van hee7 }\end{array}$ & $\begin{array}{c}\text { Phone } \\
376-9112\end{array}$ & $\begin{array}{c}\text { Inspection Date } \\
04 / 17 / 95\end{array}$ \\
\hline $\begin{array}{l}\text { Project Number } \\
2 \mathrm{H}-94-01766 / \mathrm{F}\end{array}$ & $\begin{array}{l}\text { Inspector } \\
\text { DO Wallace }\end{array}$ & $\begin{array}{c}\text { Phone } \\
372-2290\end{array}$ & $\begin{array}{c}\text { Building Number } \\
277-W\end{array}$ \\
\hline Cause Code & $\begin{array}{l}\text { Code References } \\
1993 \text { \& DOE 6430.1A }\end{array}$ & $\cdot$ & Keywords \\
\hline \hline
\end{tabular}

Condition (What is Requested?)

Status the present condition of RMCST Exhauster Skids, work packages $2 \mathrm{H}-94-01766 / \mathrm{F}$ and $2 \mathrm{H}-94-00490 / \mathrm{F}$.

\section{Comment}

1) Verify AMC Data Logger Cabinet is listed/labeled as a unit. Article 110-3 and DOE 6430.1A paragraph 1605-1.

2) Electrical Power Distribution Panel junction box, the equipment grounding conductor is required to be bonded to the box. Article 250-114(a).

No 3). The grounding electrode conductor installed from Panelboard (fed from $15 \mathrm{KVA}$ transformer) is required to be installed in one continuous length without a splice or joint. Article 250-91(a).

4) External Wiring Connection Panel junction box is required to be accessible, Article 370-29. This is questionable.

Approved For:

Cover [] Service [] Final []

\begin{tabular}{|lr|lr||}
\hline \hline Recheck 1 & Pass/Fail [ ] & Recheck 2 & Pass/Fai] [ ] \\
\hline Verified By & Date & Verified By & Date \\
\hline Status & & & \\
\hline
\end{tabular}


Send To: M Parsons T2-10

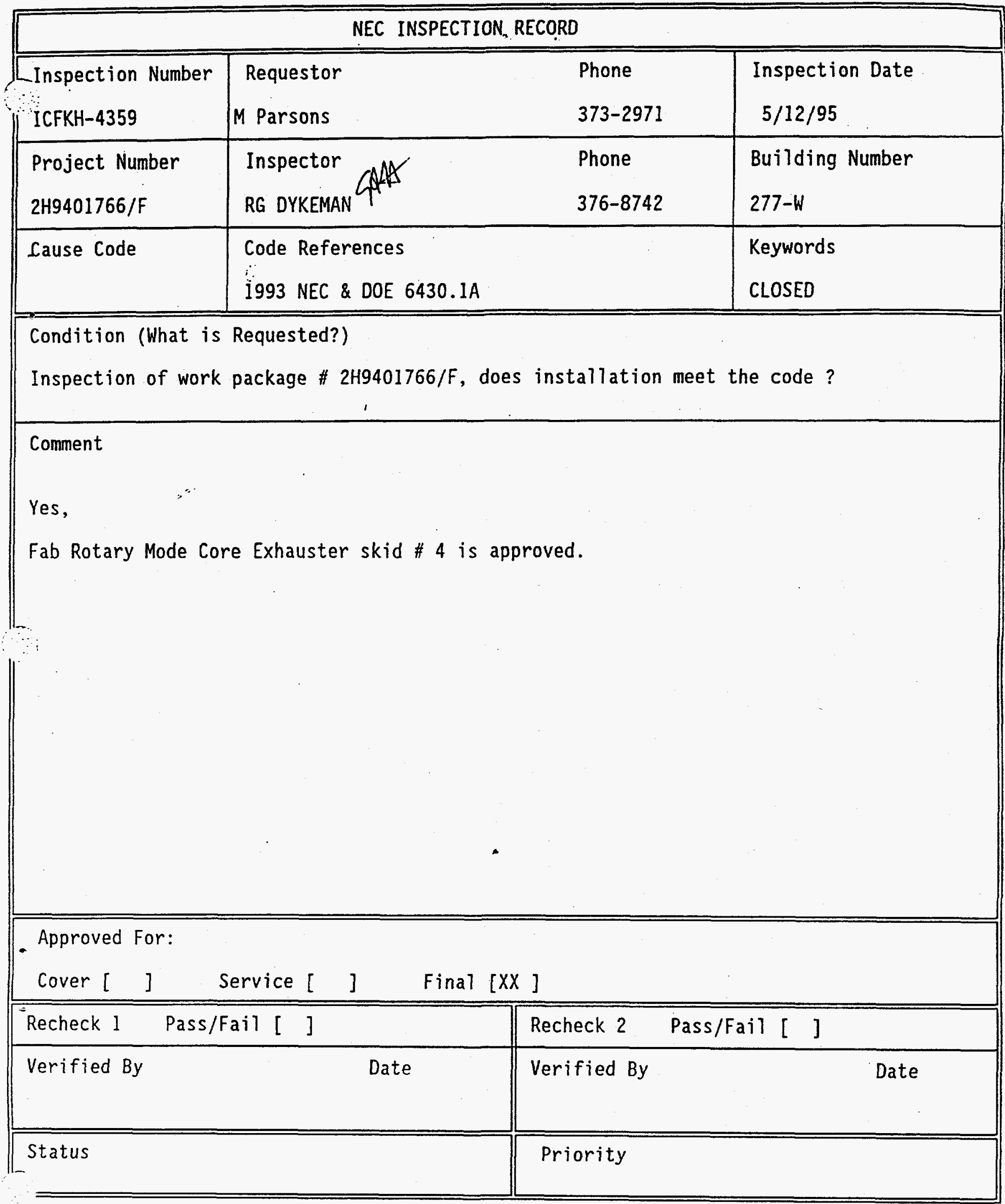




\section{Send To: Jeff van HeeT E6-38}

NEC INSPECTION RECORD

\begin{tabular}{||l|ll|l|}
\hline \begin{tabular}{|l} 
ispection Number \\
ICFKH-4364
\end{tabular} & $\begin{array}{l}\text { Requestor } \\
\text { Jeff van Hee }\end{array}$ & $\begin{array}{l}\text { Phone } \\
376-9112\end{array}$ & $\begin{array}{l}\text { Inspection Date } \\
5 / 16 / 95\end{array}$ \\
\hline Project Number & $\begin{array}{l}\text { Inspector } \\
\text { D.0. Wal1ace }\end{array}$ & Phone & Building Number \\
& $372-2290$ & $272-\mathrm{E}$ \\
\hline Cause Code & Code References & Keywords \\
& I993 NEC \& DOE 6430.1A & & Open \\
\hline
\end{tabular}

Condition (What is Requested?)

Block inspection of fabrication shop work packages.

Comment

Inspection of work in progress of the following packages:

$2 \mathrm{H}-9400546 \mathrm{~F}$ - Support truck wiring

$2 \mathrm{H}-9400705 \mathrm{~F}$ - Support truck wiring

$2 \mathrm{H}-9401266 \mathrm{~F}$ - Suspended solids

$2 \mathrm{H}-9401215 \mathrm{~F}$ - 107-AN Caustic Inj. Pump Transducers

- $-9500279 \mathrm{~F}$ - Fab 2 Densitometer Assemblies

cr-9500059F - Fab 2 Leak Detectors

$2 \mathrm{H}-9500116 \mathrm{~F}$ - Jet Pump BY-103

$2 \mathrm{H}-9500117 \mathrm{~F}$ - Jet Pump BY-105

$2 \mathrm{H}-9500118 \mathrm{~F}$ - Jet Pump BY-106

To date, all work complies with NEC.

Approved For:

Cover [ ] Service [ ] Final [ ]

\begin{tabular}{|l||lll|}
\hline \hline Recheck 1 Pass/Fail [ ] & Recheck 2 Pass/Fail [ ] & \\
\hline Verified By & Date & & \\
\hline - Status & Priority & & \\
\hline
\end{tabular}


Send To: RS McMurphy S2-39

\begin{tabular}{|c|c|c|c|}
\hline \multicolumn{4}{|c|}{ NEC INSPECTION RECORD } \\
\hline $\begin{array}{l}\text { Inspection Number } \\
\text { ICFKH- } 4369\end{array}$ & $\begin{array}{l}\text { Requestor } \\
\text { Ron McMurphy }\end{array}$ & $\begin{array}{l}\text { Phone } \\
373-2477\end{array}$ & $\begin{array}{l}\text { Inspection Date } \\
5 / 22 / 95\end{array}$ \\
\hline $\begin{array}{l}\text { Project Number } \\
2 \mathrm{IT}-9400705 \mathrm{~F}\end{array}$ & $\begin{array}{l}\text { Inspector } \\
\text { Do Wallace } 9.0 \text { wavace }\end{array}$ & $\begin{array}{l}\text { Phone } \\
372-2290\end{array}$ & $\begin{array}{l}\text { Building Number } \\
272-E\end{array}$ \\
\hline Cause Code & $\begin{array}{l}\text { Code References } \\
1993 \text { NEC \& DOE } 6430.1 \mathrm{~A}\end{array}$ & & $\begin{array}{l}\text { Keywords } \\
\text { Closed }\end{array}$ \\
\hline
\end{tabular}

Condition (What is Requested?)

Inspection of motor starter and load center installed per drawing H-2-81853 sheet 2 . Does installation meet NEC requirements?

\section{Comment}

Yes, installation is approved for service.

Approved for:

Cover [ ] Service [XX] Final [ ]

Recheck 1 Pass/Fail [ ]

Verified By

Date

\begin{tabular}{|lll|}
\hline Recheck 2 Pass/fail [ ] & \\
\hline Verified By & Date \\
\hline Priority & \\
\hline
\end{tabular}




\section{Send To: J. VanHeel E6-38}

Page 53

\begin{tabular}{|c|c|c|c|}
\hline \multicolumn{4}{|c|}{ NEC INSPECTION RECORD } \\
\hline $\begin{array}{l}\text { Inspection Number } \\
\text { ICFKH-4365 }\end{array}$ & $\begin{array}{l}\text { Requestor } \\
\text { J. VanHeel }\end{array}$ & $\begin{array}{l}\text { Phone } \\
376-9112\end{array}$ & $\begin{array}{l}\text { Inspection Date } \\
5 / 16 / 95\end{array}$ \\
\hline $\begin{array}{l}\text { Project Number } \\
2 \mathrm{H} 9401113 / \mathrm{F}\end{array}$ & Inspector & $\begin{array}{l}\text { Phone } \\
372-2290\end{array}$ & $\begin{array}{l}\text { Building Number } \\
272-E\end{array}$ \\
\hline Cause Code & $\begin{array}{l}\text { Code References } \\
1993 \text { NEC \& DOE } 6430.1 \mathrm{~A}\end{array}$ & & $\begin{array}{l}\text { Keywords } \\
\text { OPEN }\end{array}$ \\
\hline \multicolumn{4}{|c|}{$\begin{array}{l}\text { Condition (What is Requested?) } \\
\text { Inspect Decant Pump Controller Panel. Does panel meet NEC requirements? }\end{array}$} \\
\hline \multicolumn{4}{|c|}{$\begin{array}{l}\text { Comment } \\
\text { Work in progress. } \\
\text { Verify UL listing as per NEC Article } 110-3(\text { b) and DOE } 6430.1 \text { A paragraph 1605-1. }\end{array}$} \\
\hline $\begin{array}{l}\text { Approved For: } \\
\text { Cover }[]\end{array}$ & Service [ ] & ] & \\
\hline Recheck 1. Pass/ & Eail [ ] & Recheck 2 & ait [ ] \\
\hline Verified By & Date & Verified By & Date \\
\hline tatus & & Priority & \\
\hline
\end{tabular}


Send To: J. VanHeel E6-38

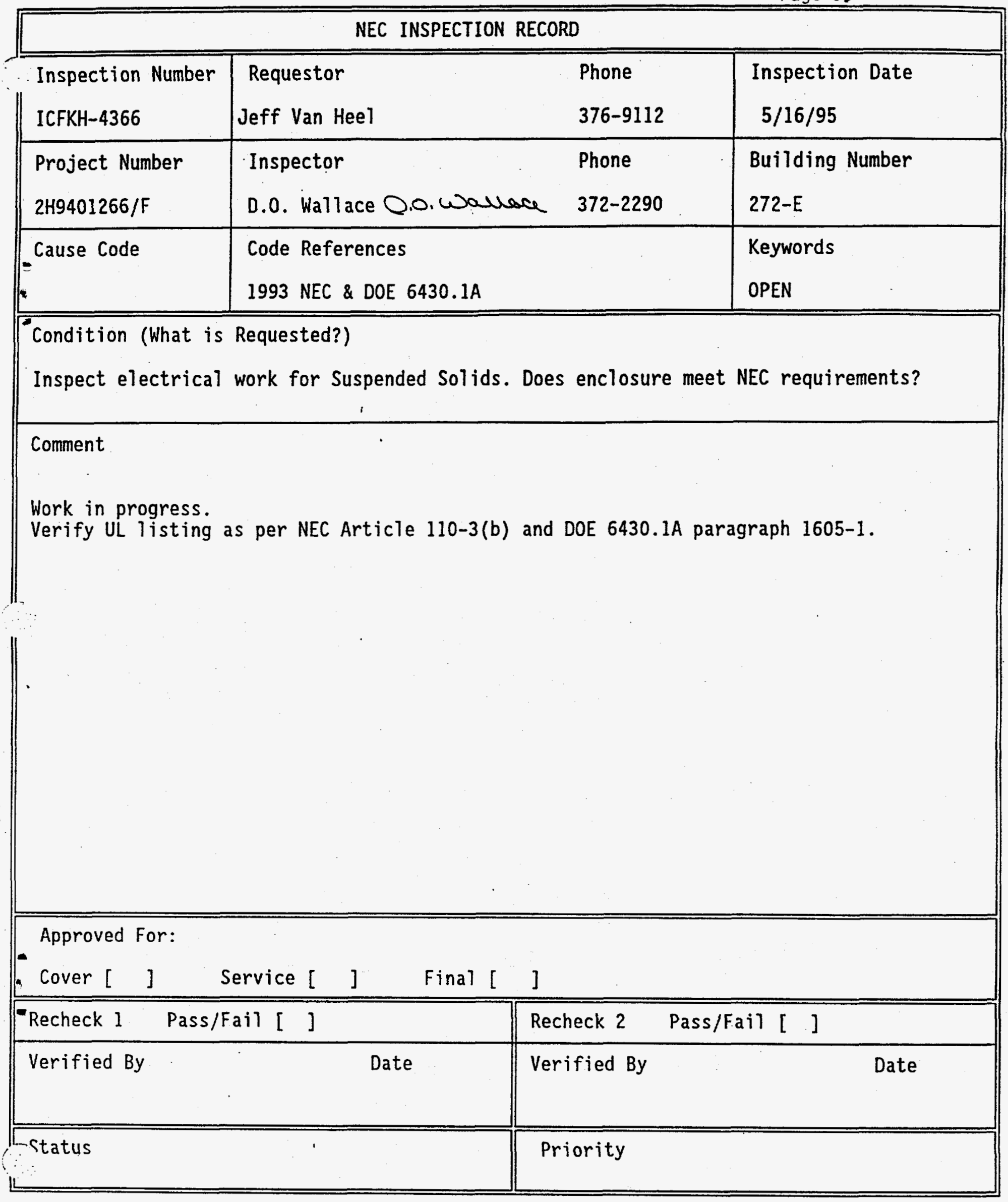




\begin{tabular}{|c|c|c|c|}
\hline \multicolumn{4}{|c|}{ NEC INSPECTION RECORD } \\
\hline $\begin{array}{l}\text { inspection Number } \\
\text { ICFKH-4370 }\end{array}$ & $\begin{array}{l}\text { Requestor } \\
\text { Jeff van Heel }\end{array}$ & $\begin{array}{l}\text { Phone } \\
376-9112\end{array}$ & $\begin{array}{l}\text { Inspection Date } \\
5 / 22 / 95\end{array}$ \\
\hline $\begin{array}{l}\text { Project Number } \\
2 \mathrm{H}-9500400 \mathrm{~F}\end{array}$ & $\begin{array}{l}\text { Inspector } \\
\text { D.0. Wallace Do. Wal }\end{array}$ & $\begin{array}{l}\text { Phone } \\
\text { ace } 372-2290\end{array}$ & $\begin{array}{l}\text { Building Number } \\
272-E\end{array}$ \\
\hline Cause Code & $\begin{array}{l}\text { Code References } \\
1993 \text { NEC \& DOE } 6430.1 \mathrm{~A}\end{array}$ & & $\begin{array}{l}\text { Keywords } \\
\text { OPEN }\end{array}$ \\
\hline \multicolumn{4}{|c|}{$\begin{array}{l}\text { Condition (What is Requested?) } \\
\text { Inspection of 107-AN Caustic Mixing Skid. Does installation meet NEC requirements. }\end{array}$} \\
\hline \multicolumn{4}{|c|}{$\begin{array}{l}\text { Comment } \\
\text { Work in progress, to date, all work complies with NEC. }\end{array}$} \\
\hline $\begin{array}{l}\text { Approved For: } \\
\text { Cover [ ] }\end{array}$ & Service [ ] Final [ & ] & \\
\hline Recheck 1 Pass/ & Fail [ ] & Recheck 2 & ail [ ] \\
\hline Verified By & Date & Verified By & Date \\
\hline Status & $\overline{1}$ & Priority & \\
\hline
\end{tabular}


WHC

K. J. Dempsey $\quad 57-40$

J. L. Lee R2-50

K. W. Leliefeld R2-88

R. E. Lerch $57-85$

J. C. Midgett S7-81

P. H. Thomsen R2-88

J. E. Truax R2-50

A. M. Umek S7-81

J. Weber S1-57

ICF Kaiser

J. G. Holyoak

J. M. Roberts

R. M. Tanner

J. D. Van Heel

D. 0. Wallace

Central Files

0.S.T.I (2)

DOE-RL Public Reading Room

Document Processing \& Dist
T2-08

A4-70

$\mathrm{N} 1-23$

E6-38

S2-56

$\mathrm{H} 2-53$

L8-15 